\title{
Targeting Inhibitor of $\kappa B$ Kinase $\beta$ Prevents Inflammation-Induced Preterm Delivery by Inhibiting IL-6 Production from Amniotic Cells
}

Aska Toda, ${ }^{*}$ Kenjiro Sawada, ${ }^{*}$ Tomoyuki Fujikawa, ${ }^{\dagger}$ Atsuko Wakabayashi, ${ }^{\ddagger}$ Koji Nakamura, ${ }^{*}$ Ikuko Sawada, ${ }^{*}$ Akihiko Yoshimura, ${ }^{*}$ Erika Nakatsuka, ${ }^{*}$ Yasuto Kinose, ${ }^{*}$ Kae Hashimoto, ${ }^{*}$ Seiji Mabuchi, ${ }^{*}$ Atsushi Tokuhira, Masahiro Nakayama, "Akiko Itai, ${ }^{\dagger}$ Hirohisa Kurachi," and Tadashi Kimura*

From the Department of Obstetrics and Gynecology, * Osaka University Graduate School of Medicine, Osaka; IMMD Inc., ${ }^{\dagger}$ Tokyo; the Laboratory of Infection and Prevention Institute for Virus Research, ${ }^{\ddagger}$ Kyoto University, Kyoto; the Department of Obstetrics and Gynecology, ${ }^{\S}$ Toyonaka Municipal Hospital, Osaka; and the Departments of Clinical Laboratory Medicine and Anatomic Pathology" and Obstetrics and Gynecology," Osaka Medical Center and Research Institute for Maternal and Child Health, Osaka, Japan

Accepted for publication November 10, 2015.

Address correspondence to Kenjiro Sawada, M.D., Ph.D., Department of Obstetrics and Gynecology, Osaka University School of Medicine, 2-15 Yamadaoka Suita, Osaka, Japan 5650871. E-mail: daasawada@gyne.med.osaka-u. ac.jp.

\begin{abstract}
Preterm delivery (PTD) remains a serious challenge in perinatology. Intrauterine infection and/or inflammation, followed by increased inflammatory cytokines, represented by IL-6, are involved in this pathology. Our aim was to identify IL-6-producing cells in the placenta and to analyze the potential of targeting I $\mathrm{B}$ B kinase $\beta$ (IKK $\beta$ ) signaling to suppress IL- 6 production for the treatment of PTD. Immunohistochemical analyses using placentas complicated with severe chorioamnionitis revealed that IL-6 is mainly expressed in human amniotic mesenchymal stromal cells (hAMSCs). Primary hAMSCs were collected, and strong IL-6 expression was confirmed. In hAMSCs, the treatment of tumor necrosis factor- $\alpha$ or IL-1 $\beta$ drastically induced IL- 6 production, followed by the phosphorylation of IKKs. A novel IKK $\beta$ inhibitor, IMD-0560, almost completely inhibited IL-6 production from hAMSCs. Using an experimental lipopolysaccharide-induced PTD mouse model, the therapeutic potential of IMD-0560 was examined. IMD-0560 was delivered vaginally 4 hours before lipopolysaccharide administration. Mice in the IMD-0560 $(30 \mathrm{mg} / \mathrm{kg}$, twice a day) group had a significantly lower rate of PTD [10 of $22(45 \%)$ ] without any apparent adverse events on the mice and their pups. In uteri collected from mice, IMD-0560 inhibited not only IL- 6 production but also production of related cytokines, such as keratinocyte-derived protein chemokine/CXCL1, macrophage inflammatory protein-2/CXCL2, and monocyte chemoattractant protein-1/chemokine ligand 2. Targeting IKK $\beta$ signaling shows promising effects through the suppression of these cytokines and can be explored as a future option for the prevention of PTD. (Am J Pathol 2016, 186: 616-629; http://dx.doi.org/ 10.1016/j.ajpath.2015.11.004)
\end{abstract}

Preterm delivery (PTD; before 37 completed weeks in humans) is the leading cause of perinatal morbidity and mortality and remains a significant public health concern worldwide. ${ }^{1}$ PTD occurs in up to $10 \%$ of all pregnancies and is associated with $75 \%$ of infant mortality and $50 \%$ of longterm neurological handicaps. ${ }^{2,3}$ Currently, tocolytic agents, such as $\beta$-adrenergic agonists, magnesium sulfate, or antibiotics, are administered when indicated; however, tocolysis with these drugs is rarely successful beyond 24 to 48 hours because these medications do not alter the fundamental mechanism of labor activation. ${ }^{4}$ Although the etiology is multifactorial, approximately $25 \%$ to $40 \%$ of PTDs are associated with an underlying infectious process. ${ }^{2}$

Intrauterine infection, represented by chorioamnionitis (CAM), is an acute inflammation of the membranes and chorion of the placenta, typically caused by ascending

Supported by the Ministry of Education, Science, Sports, and Culture of Japan grants-in-aid for scientific research 24592515, 26670725, and 26293360 (K.S.) and 24249080 (T.K.).

Disclosures: The MR16-1 antibody was provided by Chugai Pharmaceutical Co., Ltd. (Shizuoka, Japan). 
bacterial infection. CAM complicates one-third of the patient population with PTD and is the most common complication associated with preterm premature rupture of membranes. ${ }^{5,6}$ At the inflammatory site, leukocytes, such as neutrophils or macrophages, are recruited, activated, and secrete proinflammatory cytokines, including tumor necrosis factor (TNF)- $\alpha$ or IL-1 $\beta$, in response to bacteria or bacterial products $\left[\mathrm{eg}\right.$, lipopolysaccharide (LPS)]. ${ }^{7}$ These cytokines synthesize secondary mediators, such as prostaglandins and matrix metalloproteinases, which contribute to preterm labor, preterm premature rupture of membranes, and onset of PTD. ${ }^{8}$ In addition, CAM often predisposes the preterm infant to developmental delay and lifelong neurological impairments caused by perinatal brain damage. ${ }^{6,9}$ In the preterm infant brain complicated with periventricular leukomalacia, an increased expression of proinflammatory cytokines has been identified, indicating that these may mediate infection-induced fetal or neonatal brain injury. ${ }^{10}$ Therefore, targeting these cytokines can be a promising approach to reduce not only PTD but also its associated disorders of neonates.

It is well known that the increased concentration of proinflammatory cytokines, such as IL-6 and IL-8, in a variety of biological fluids, including amniotic fluid, fetal cord blood, maternal serum, urine, cervical, or vaginal secretions, and placental tissues, is an independent risk factor for PTD. ${ }^{11}$ In particular, various studies have indicated that local IL-6 expression appears to be the best marker for detecting intrauterine infection/inflammation, as well as for identifying patients at risk of PTD and neonatal complications. ${ }^{12}$ However, most previous reports focusing on IL-6 have predominantly paid attention to its potential as a predictor of CAM or PTD, ${ }^{13}$ whereas little has been reported regarding the therapeutic potential of targeting this cytokine, even though IL-6 appears to be indispensable in the etiology of these diseases. Recently, anticytokine therapies have emerged in the clinical setting, as is represented by tocilizumab (Chugai Pharmaceutical, Tokyo, Japan), a humanized antihuman IL-6 receptor antibody, for the treatment of Castleman's disease and rheumatoid arthritis. ${ }^{14}$ Recently, we demonstrated the potential of tocilizumab to treat inflammation-induced PTD.$^{15}$ However, tocilizumab has a molecular weight of 148,000 and does not appear to reach the maternal-fetal interface easily, although it has been shown that local inflammation at the maternal-fetal interface, rather than systemic inflammation, is much more critical in the etiology of PTD. ${ }^{16}$ Thus, a small-molecule compound that efficiently inhibits IL-6 production with a good safety profile is likely to be feasible for the treatment of PTD.

The promoter region of the ILC gene has a putative NF$\kappa \mathrm{B}$ binding site, and IL- 6 expression is known to be regulated by NF- $\kappa B$ signaling. ${ }^{17}$ The NF- $\kappa B /$ Rel family includes

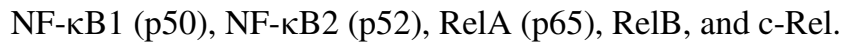
They can form homodimers and heterodimers, with the most abundant form being $\mathrm{p} 50 / \mathrm{p} 65 .{ }^{18,19}$ These dimers are present in the cytosol in an inactive form, complexed with the I $\mathrm{B}$ family proteins. The NF- $\mathrm{B}$ pathway can be rapidly activated by a wide variety of substances, such as mitogens, cytokines, and microbial components. On stimulation, phosphorylation of I $\mathrm{KB}$ by I $\kappa \mathrm{B}$ kinases (IKKs) leads to degradation of $\mathrm{I} \kappa \mathrm{B}$ and renders NF- $\kappa \mathrm{B}$ dimers free to translocate into the nucleus, and NF- $\kappa \mathrm{B}$ binds to promoters and enhancers, leading to an increase in gene transcription. Two I $\kappa \mathrm{B}$ kinases, IKK $\alpha$ and $\operatorname{IKK} \beta$, have been described, and gene-targeting experiments have revealed that many proinflammatory stimuli require the IKK $\beta$ subunit for NF- $\kappa \mathrm{B}$ activation, ${ }^{20}$ indicating that IKK $\beta$ might be involved in the pathogenesis of PTD induced by inflammation.

IMD-0560, or N-[2,5-bis(trifluoromethyl)phenyl]-5-bromo2-hydroxybenzamide, was developed as a novel IKK inhibitor. The molecular structure of IMD-0560 was designed by analyzing the binding of aspirin to IKK $\beta .^{19,21,22}$ Thus, IMD0560 acts as a selective IKK $\beta$ inhibitor, blocks I $\mathrm{B} \alpha$ phosphorylation, and prevents NF- $\kappa \mathrm{B}$ p65 nuclear translocation. Its prodrug is currently under assessment in a clinical trial for inflammation-related cardiovascular diseases and rheumatoid arthritis. ${ }^{21,23}$ Okazaki et al ${ }^{24}$ reported that IMD-0560 potently inhibited TNF- $\alpha$-induced IL- 6 production in human fibroblastlike synoviocytes derived from patients with rheumatoid arthritis without causing cell toxicity, suggesting that this drug can serve as a novel inhibitor of IL- 6 production.

With this in mind, our aim was to identify IL-6producing cells in CAM-complicated placentas by immunohistochemical analyses using anti-IL-6 and phosphorylated-IKK antibodies. Furthermore, the therapeutic potential of the selective IKK $\beta$ inhibitor, IMD0560, to inhibit inflammation-induced PTD was assessed in vitro and in vivo.

\section{Materials and Methods}

\section{Materials}

The synthetic IKK $\beta$ inhibitor IMD-0560 was supplied by IMMD Inc. (Tokyo, Japan). Antibodies against cytokeratin 18 (RGE53) and IL-6 (sc-130326) were purchased from Santa Cruz Biotechnology (Santa Cruz, CA). Antibodies against phospho-IKK $\alpha / \beta$ (16A6), phospho-IкB- $\alpha$ (14D4), IкB- $\alpha$, NF- $\mathrm{Bp} 65$ (D14E12), vimentin (R28), and $\beta$-actin were purchased from Cell Signaling Technology (Danvers, MA). Recombinant human TNF- $\alpha$, IL-1 $\beta$, LPS from Escherichia coli (serotype 055:B05), and RU486 were purchased from Sigma-Aldrich (St. Louis, MO). Anti-mouse IL-6 receptor (IL-6R) antibody, MR16-1, was kindly provided by Chugai Pharmaceutical Co Ltd (Shizuoka, Japan). MG132 was from Enzo, Life Sciences (Farmingdale, NY). Nonimmune mouse $\mathrm{IgG}$ was purchased from Jackson Immuno Research (West Grove, PA).

\section{Placental Tissue Collection}

Sections of placental tissues were obtained from patients with CAM-complicated PTDs $(n=8)$ and noninfectious 
control subjects $(n=9)$ at the Osaka Medical Center and Research Institute for Maternal and Child Health, Toyonaka Municipal Hospital, and the Osaka University Medical Hospital (all in Osaka, Japan) between 2011 and 2014. Use of clinical samples was approved by the ethics committees of each institute, and written informed consent was obtained from each patient. Patients complicated with CAM were clinically diagnosed with maternal fever $\left(\geq 37.8^{\circ} \mathrm{C}\right)$ and at least two or more of the following clinical criteria: maternal tachycardia (100 beats/minute) or fetal tachycardia (160 beats/minute), maternal leukocytosis $(>15,000 / \mu \mathrm{L})$, uterine tenderness, or foul-smelling amniotic fluid at the time of the speculum examination. ${ }^{25}$ Placentas were also histologically diagnosed, according to the criteria of Blanc, ${ }^{26}$ as having 10 neutrophils per high-power field in the sub-chorionic space, chorion, or placental plate.

\section{Immunohistochemistry}

Formalin-fixed, paraffin-embedded tissue blocks were sliced into sections ( $4 \mu \mathrm{m}$ thick). The sections were deparaffinized in xylene and dehydrated with $100 \%$ ethanol. Antigen unmasking was performed by boiling the sections in Target Retrieval Solution ( $\mathrm{pH}$ 9.0; Dako, Glostrup, Denmark). After being placed in $3 \% \mathrm{H}_{2} \mathrm{O}_{2}$ and blocked with Blocking Solution (Dako), the sections were incubated with the primary antibodies against IL- 6 and $\mathrm{p}-\mathrm{IKK} \alpha / \beta$ at $1: 40$ for 1 hour at room temperature. After washing with Tris-buffered saline containing $0.1 \%$ Tween-20, the slides were stained using the Envision system (Dako), followed by the application of 3,3-diaminobenzidine solution (Dako) until the wanted stain intensity developed, and then were counterstained with Mayer's hematoxylin.

\section{Isolation of hAMSCs}

Human primary amniotic mesenchymal stromal cells (hAMSCs) were obtained using the method, as previously reported, ${ }^{15}$ and reviewed by Parolini et al. ${ }^{27}$ Briefly, amniotic membranes were collected from the placentas of patients who had undergone uncomplicated cesarean sections at term at Osaka University Medical Hospital (Suita, Japan) between 2012 and 2014. None of the patients from whom specimens were obtained had experienced labor. Written informed consent was obtained from each patient before surgery. For isolation of amniotic cells, amniotic membranes were stripped from the underlying chorion, washed, minced into small pieces ( 1 to $2 \mathrm{~mm}$ thick), and digested with $0.05 \%$ trypsin at $37^{\circ} \mathrm{C}$ for 1 hour. Thereafter, the pieces were placed in Dulbecco's modified Eagle's medium (DMEM) containing 10\% fetal bovine serum for 20 seconds and strained through $40-\mu \mathrm{m}$ nylon mesh. The elute was collected and centrifuged at $1200 \times g$ for 10 minutes, and the precipitate was cultured as human primary amniotic epithelial cells (hAECs). After centrifugation to remove epithelial cells, the pieces were further incubated in $0.01 \%$ collagenase at $37^{\circ} \mathrm{C}$ for 1 hour, strained, and centrifuged as well, and the precipitate was cultured as hAMSCs in $10 \%$ fetal bovine serum/DMEM and $1 \%$ penicillin/streptomycin solution (Life Technologies, Carlsbad, CA). Cells were cultured in a $95 \%$ air $-5 \% \mathrm{CO}_{2}$ incubator at $37^{\circ} \mathrm{C}$ and used for subsequent experiments within passage 3 or 4 .

\section{RT-PCR Analysis}

Total RNA was extracted using TRI REAGENT (Molecular Research Center, Inc., Cincinnati, OH), and cDNA was synthesized from $1 \mu \mathrm{g}$ RNA using a ReverTra Ace qPCR RT Master Mix (Toyobo, Osaka, Japan) with random primers. The cDNA templates were PCR amplified with Taq PCR master mix (Qiagen, Valencia, CA), as previously reported, ${ }^{15}$ under the following conditions: 35 cycles of $94^{\circ} \mathrm{C}$ for 30 seconds, $60^{\circ} \mathrm{C}$ for 45 seconds, and $72^{\circ} \mathrm{C}$ for 60 seconds. The products were depicted by electrophoresis on $1.5 \%$ agarose gels containing ethidium bromide and visualized by UV illumination. The primers used were designed on the basis of our previous report ${ }^{15}$ and that of Nakanishi et al..$^{28}$ The primer sequences and the expected PCR products were as follows: IL-6, $5^{\prime}$-TAGCCGCCCCACACAGACAG- $3^{\prime}$ (sense) and $5^{\prime}$-GGCTGGCATTTGTGGTTGGG-3' (antisense) (size, 408 bp); IL-6R, 5'-CATTGCCATTGTTCTGAGGTTC-3' [sense; bases 1580 to 1601: this primer annealed to the region splicing out from IL-6R; therefore, soluble IL-6R (sIL-6R) transcript could not be amplified] and 5'-GTGCCACCCAGCCAGCTATC-3' (antisense; bases 1840 to 1859) (size, 280 bp); sIL-6R, 5'-TCCACCCCCATGCAGGCACT-3' (sense; bases 1419 to 1438) and 5'-GTGCCACCCAGCCAGCTATC-3' (antisense; bases 1840 to 1859 , same as IL6R-antisense) (size, $441 \mathrm{bp}$ for IL-6R and $341 \mathrm{bp}$ for sIL-6R); gp130, 5'-GCAAGACATGTTGACGTTGCAGAGACTTTG-3' (sense) and 5'-GGGCATTCTCTGCTTCTACCCAGAC- $3^{\prime}$ (antisense) (size, $615 \mathrm{bp}$ ); and $\beta$-actin, $5^{\prime}$-CGTGACATTAAGGAGCTGTG-3' (sense) and 5'-GCTCAGGAGGAGCAATGATCTTGA-3' (antisense) (size, 376 bp). The sequences of cDNA were on the basis of GenBank data (http://www.ncbi.nlm.nih.gov/nuccore; accession number NM_000600 for IL-6, X12830 for IL-6R and sIL-6R, NM_002184 for gp130, and NM_001101 for $\beta$-actin).

\section{Cell Viability Assessment}

A total of $5 \times 10^{3}$ primary hAMSCs were seeded in 96-well plates. The cells were cultured in DMEM supplemented with $10 \%$ fetal bovine serum with increasing concentrations of IMD-0560 ranging from 0.1 to $1.0 \mu \mathrm{mol} / \mathrm{L}$ for 24 hours. Cell viability was assessed using the CellTilter 96 AQueous One Solution Cell Proliferation Assay kit (Promega, Madison, WI). The optical density was measured at $490 \mathrm{~nm}$. Cell viability was expressed as the ratio of the number of viable cells with IMD-0560 treatment/the number without treatment. 


\section{Western Blot Analysis}

A total of $1 \times 10^{6}$ primary hAMSCs were seeded onto 6-well plates and allowed to attach overnight. Thereafter, cells were cultured in $0.1 \%$ bovine serum albumin (BSA)/DMEM with various concentrations of IMD-0560 for 24 hours. Cultures were pretreated for 2 hours with $20 \mu \mathrm{mol} / \mathrm{L} \mathrm{MG132} \mathrm{(pro-}$ teasome inhibitor) before stimulation by $10 \mathrm{ng} / \mathrm{mL}$ TNF- $\alpha$ for 30 minutes. Cells were lysed with $1 \times$ cell lysis buffer [20 $\mathrm{mmol} / \mathrm{L}$ Tris- $\mathrm{HCl}$ (pH 7.5), $150 \mathrm{mmol} / \mathrm{L} \mathrm{NaCl}, 1 \mathrm{mmol} / \mathrm{L}$ $\mathrm{Na}_{2}$ EDTA, $1 \mathrm{mmol} / \mathrm{L}$ EGTA, $1 \%$ Triton, $2.5 \mathrm{mmol} / \mathrm{L}$ sodium pyrophosphate, $1 \mathrm{mmol} / \mathrm{L} \beta$-glycerophosphate, 1 $\mathrm{mmol} / \mathrm{L} \mathrm{Na} \mathrm{VO}_{4}, 1 \mathrm{mg} / \mathrm{mL}$ leupeptin, and $1 \mathrm{mmol} / \mathrm{L}$ phenylmethylsulfonyl fluoride] (Cell Signaling, Beverly, MA). Lysates were separated by $10 \%$ SDS-PAGE and transferred to a polyvinylidene difluoride membrane, followed by incubation with the primary antibodies (phospho-IкB- $\alpha$, 1:50; IкB- $\alpha, 1: 1000$; and $\beta$-actin, 1:3000) in blocking one solution (Nacalai Tesque, Kyoto, Japan) and then with the corresponding secondary horseradish peroxidase-conjugated IgG. The proteins were visualized with the electrochemiluminescence reagents (PerkinElmer Life Science, Boston, MA).

\section{Immunofluorescence Analysis}

A total of $1 \times 10^{4}$ primary hAMSCs were plated onto an eight-chamber glass slide and allowed to attach overnight. Cells were cultured in $0.1 \%$ BSA/DMEM with $1 \mu \mathrm{mol} / \mathrm{L}$ IMD-0560 for 24 hours and then stimulated with $10 \mathrm{ng} / \mathrm{mL}$ TNF- $\alpha$ for 1 hour. Thereafter, cells were fixed with $4 \%$ paraformaldehyde and stained with rabbit anti-human NF- $\kappa \mathrm{B}$ p65 antibodies at $1: 200$ at $4{ }^{\circ} \mathrm{C}$ overnight. After washing, samples were incubated with 1:200 Alexa Fluor 555-labeled goat anti-rabbit IgG (A-21429; Life Technologies, Carlsbad, CA) and finally stained with DAPI. The samples were observed using an FV1000-D Laser Scanning Confocal microscope (Olympus, Tokyo, Japan).

\section{Quantification of IL-6}

A total of $5 \times 10^{5}$ primary hAMSCs were plated onto 12-well plates and allowed to attach overnight. Cells were cultured in $0.1 \% \mathrm{BSA} / \mathrm{DMEM}$ with 1 or $3 \mu \mathrm{mol} / \mathrm{L}$ IMD-0560 dissolved in dimethyl sulfoxide for 24 hours. The equivalent volume of dimethyl sulfoxide was treated as control. Thereafter, cells were stimulated with $10 \mathrm{ng} / \mathrm{mL}$ TNF- $\alpha$ or $10 \mathrm{ng} / \mathrm{mL}$ IL- $1 \beta$ for 11 hours. Total RNA was extracted, and cDNA was synthesized as described. Real-time quantitative PCR was performed using the StepOnePlus Real-Time PCR System (Applied Biosystems, Foster City, CA) with the following probes from Applied Biosystems: human IL-6 (Mm00174131_m1) and human glyceraldehyde-3-phosphate dehydrogenase (4326317E) as an internal control. Relative levels of mRNA gene expression were calculated using the $2^{-\Delta \Delta \mathrm{C}_{\mathrm{T}}}$ method, as described previously. ${ }^{29}$ For the quantitative assay of
Table 1 Clinical Characteristics of Patients

\begin{tabular}{|c|c|c|c|c|}
\hline Group & $\begin{array}{l}\text { Gestational } \\
\text { age at } \\
\text { delivery }\end{array}$ & $\begin{array}{l}\text { Mode } \\
\text { of } \\
\text { delivery }\end{array}$ & pPROM & $\begin{array}{l}\text { Gestational } \\
\text { age at } \\
\text { pPROM }\end{array}$ \\
\hline \multirow[t]{8}{*}{$\operatorname{CAM}(n=8)$} & $26 \mathrm{w}, 1 \mathrm{~d}$ & VD & No & \\
\hline & $30 w, 3 d$ & VD & Yes & $29 \mathrm{w}, 1 \mathrm{~d}$ \\
\hline & $28 \mathrm{w}, 6 \mathrm{~d}$ & VD & No & \\
\hline & $29 w, 3 d$ & VD & No & \\
\hline & $33 w, 3 d$ & CS & Yes & $32 \mathrm{w}, 2 \mathrm{~d}$ \\
\hline & $34 w, 3 d$ & CS & Yes & $33 \mathrm{w}, 0 \mathrm{~d}$ \\
\hline & $27 \mathrm{w}, 1 \mathrm{~d}$ & CS & Yes & $25 w, 2 d$ \\
\hline & $27 w, 6 d$ & CS & No & \\
\hline \multirow[t]{9}{*}{ Control $(n=9)$} & $37 \mathrm{w}, 1 \mathrm{~d}$ & VD & No & \\
\hline & $39 w, 2 d$ & VD & No & \\
\hline & $38 w, 2 d$ & VD & No & \\
\hline & $38 \mathrm{w}, 0 \mathrm{~d}$ & CS & No & \\
\hline & $37 \mathrm{w}, 1 \mathrm{~d}$ & CS & No & \\
\hline & $40 w, 0 d$ & CS & No & \\
\hline & $37 w, 2 d$ & CS & No & \\
\hline & $37 \mathrm{w}, 1 \mathrm{~d}$ & CS & No & \\
\hline & $37 \mathrm{w}, 6 \mathrm{~d}$ & CS & No & \\
\hline
\end{tabular}

CAM, chorioamnionitis; CS, cesarean section; $d$, days pPROM, preterm premature rupture of membranes; VD, vaginal delivery; $w$, weeks.

human IL-6, conditioned culture media were collected and stored at $-80^{\circ} \mathrm{C}$ until analysis. Human IL-6 Platinum ELISA (eBiosciense, Vienna, Austria) was used to determine the concentration of IL-6, with a sensitivity of $2 \mathrm{pg} / \mathrm{mL}$.

\section{Animal Experiments}

In vivo experiments using an experimental LPS-induced PTD mouse model were performed as previously reported. ${ }^{15}$ Briefly, B6D2F1 male mice and C3H/HeN female mice were purchased from Charles River Japan (Yokohama, Japan). They were housed individually under controlled conditions at $25^{\circ} \mathrm{C}$ and $60 \%$ relative humidity on a 12-hour light/12-hour dark cycle. $\mathrm{C} 3 \mathrm{H} / \mathrm{HeN}$ female null-para mice (7 to 12 weeks old) were pair-mated with $\mathrm{B} 6 \mathrm{D} 2 \mathrm{~F} 1$ male mice (7 to 30 weeks old). The day when a vaginal plug was detected was designated as 0.5 days of gestation. All pregnant mice delivered their pups on day 19 or 20. PTD was defined as delivery before 18.5 days of gestation because pups born before that day could not survive. For mouse models of endotoxin-induced PTD, on day 15.5 of gestation, $50 \mu \mathrm{g} / \mathrm{kg}$ LPS dissolved in $200 \mu \mathrm{L}$ of $0.9 \%$ saline was injected twice i.p., with a 3-hour interval between injections ( $2 \mathrm{pm}$ and $5 \mathrm{pm}$ ). In our dose-response series, $50 \mu \mathrm{g} / \mathrm{kg}$ was the lowest dose of LPS that reproducibly induced PTD, without significant morbidity or mortality, in gravid $\mathrm{C} 3 \mathrm{H} / \mathrm{HeN}$ females, on the basis of the established method reported by our previous studies, ${ }^{15}$ and by Kaga et al. ${ }^{30}$ For the prevention study, $30 \mathrm{mg} / \mathrm{kg}$ IMD-0560 mixed in Vosco S-55 (Maruishi Pharmaceutical, Osaka, Japan), a general base for suppository, was administered transvaginally 4 hours before the initial LPS treatment (at 10 am on day 15.5 
of gestation) and concomitantly with the second LPS treatment (at $5 \mathrm{pm}$ on day 15.5 of gestation). An equivalent volume of Vosco S-55 alone was administered as control. MR16-1 (anti-mouse IL-6R antibody; $12 \mathrm{mg} / \mathrm{kg}$ ) diluted in $200 \mu \mathrm{L}$ phosphate-buffered saline was administered i.p. 24 hours before LPS treatment (at $5 \mathrm{pm}$ on day 14.5 of gestation). An equivalent volume of nonimmune mouse $\operatorname{IgG}$ was administered as control IgG. RU486 was dissolved in

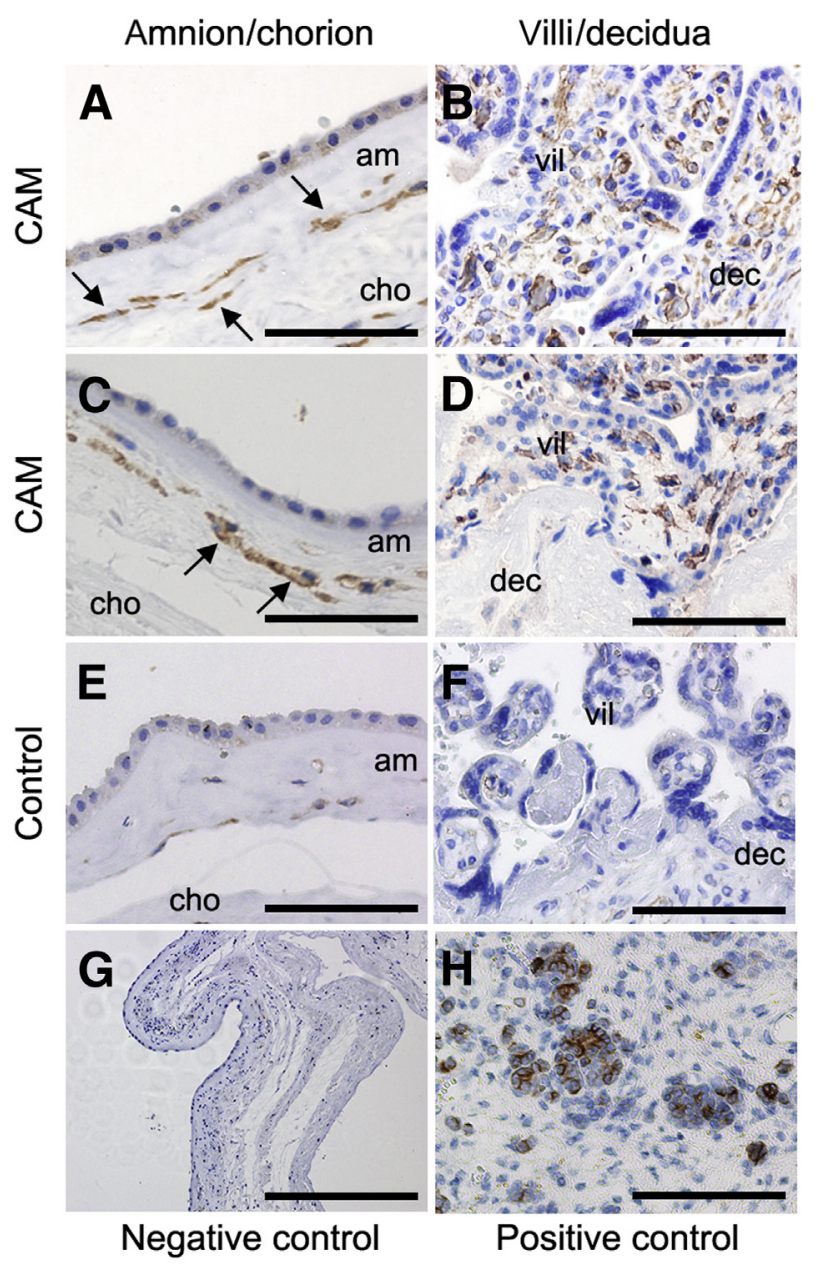

I

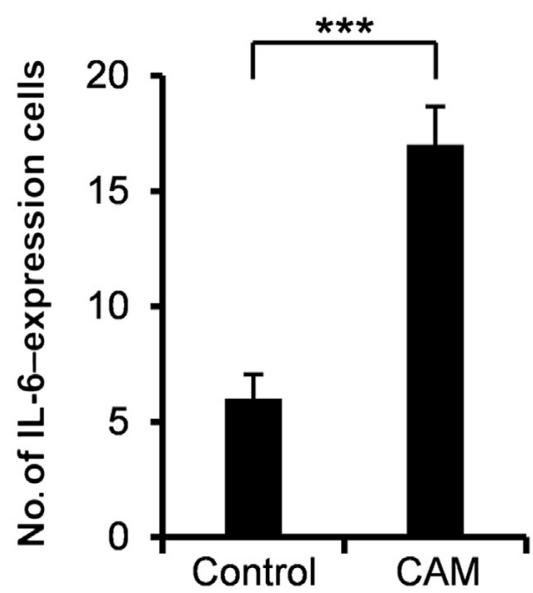

$50 \mathrm{mg} / \mathrm{mL}$ absolute ethanol and diluted in $0.9 \%$ saline solution. Then, $150 \mu \mathrm{g} / 350 \mu \mathrm{L}$ of RU486 was injected s.c. on day 16.0 of gestation to induce noninfectious premature delivery. All experimental and surgical procedures involving animals were performed in accordance with the $\mathrm{NIH}$ guidelines and were approved by the Institutional Animal Care and Use Committee of the Osaka University Graduate School of Medicine (Osaka, Japan).

\section{Measurement of Murine IL- 6 Concentration}

Murine maternal blood samples were collected from a tail vein at $2 \mathrm{pm}$ (before the initial LPS injection) and at $6 \mathrm{pm}$ (1 hour after the second LPS injection) on day $15.5 ; 100-\mu \mathrm{L}$ samples were obtained each time. The blood samples were allowed to clot for 2 hours at room temperature or overnight at $4{ }^{\circ} \mathrm{C}$, and centrifuged for 20 minutes at $2000 \times g$. Serum was removed and stored at $-80^{\circ} \mathrm{C}$ until analysis. The concentration of IL-6 was measured using the Mouse IL-6 ELISA Ready-SET-Go kit (eBioscience, San Diego, CA).

\section{Real-Time Quantitative RT-PCR of Murine Tissues}

Murine uterine tissues were obtained by cesarean section 1 hour after LPS treatment (at $6 \mathrm{pm}$ on day 15.5). The tissues were thoroughly rinsed in phosphate-buffered saline, frozen with liquid nitrogen, and stored at $-80^{\circ} \mathrm{C}$ until analysis. Total RNA was extracted, and cDNA was synthesized as described. Real-time quantitative PCR was performed using the StepOnePlus Real-Time PCR System with the following probes from Applied Biosystems: murine Il-6 (Mm00446190_m1), Kc (Mm04207460_m1), Mcp-1 (Mm00441242_m1), Mip-2 (Mm00436450_m1), and murine glyceraldehyde-3-phosphate dehydrogenase (4352339E).

\section{Murine Serum Cytokine Array}

Murine serum samples were obtained as described. Cytokine levels were measured using mouse cytokine array panel A kits (R\&D Systems, Minneapolis, MN). Membranes were exposed to X-ray for 120 seconds. The relative intensity of each spot on the membrane was

\footnotetext{
Figure 1 Immunohistochemical analyses of IL-6 expression in chorioamnionitis (CAM)-complicated placentas. A-D: Sections of the placenta were obtained from two patients who terminated her pregnancy at 28 and 29 weeks of gestation, complicated by CAM. Representative pictures from amnion (am) plus chorion (cho; A and C), and villi (vil) and decidua (dec; B and D) are shown. Arrows indicate positive-stained cells (diaminobenzidine; brown). E and F: Sections from a normal-term control subject (38 weeks of gestation). G: Negative control by nonimmune sera. H: Sections from Wilms' tumor as positive control for IL-6 staining. I: Number of IL-6-expressing cells in amnions per field in control and CAM-complicated placentas. Five representative images of amnions were randomly taken in each case. Each bar represents the means \pm SD (I). $n=9$ (I, control); $n=8$ (I, CAM-complicated placentas). ${ }^{* * *} P<0.001$ versus control. Scale bar $=100 \mu \mathrm{m}(\mathbf{A}-\mathbf{H})$. Original magnifications: $\times 200(\mathbf{A}-\mathbf{F}, \mathbf{H}$, and I); $\times 100(\mathbf{G})$.
} 

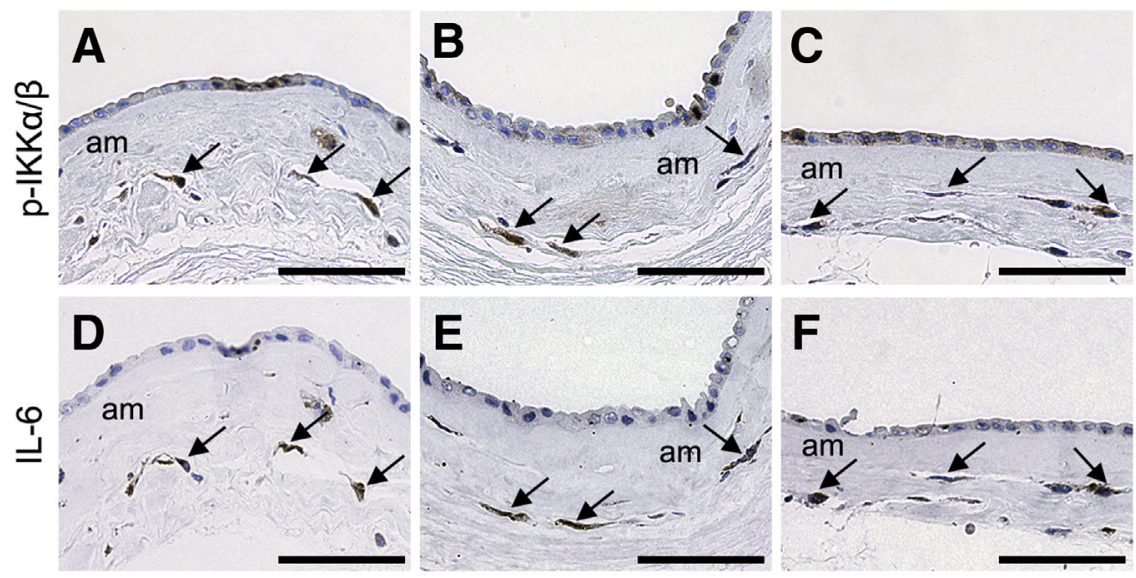

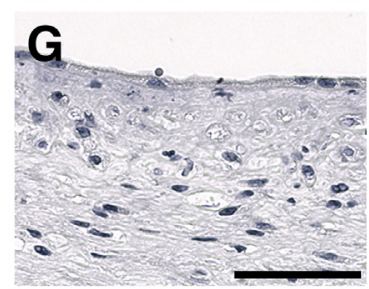

Negative control

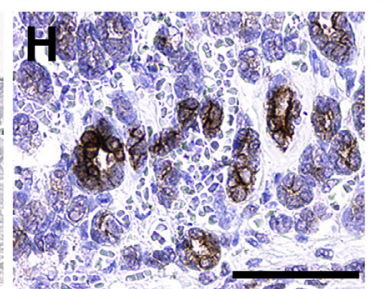

Positive control

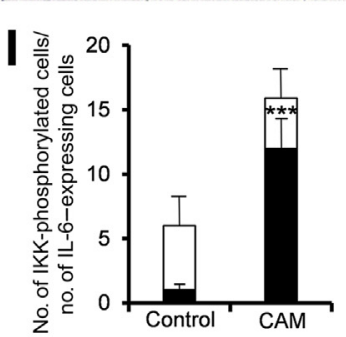

Figure 2 IL-6-expressing cells in amnions were I $\mathrm{B}$ kinase (IKK) phosphorylated in chorioamnionitis (CAM)-complicated placentas. Serial cross sections of placental bed tissues obtained from patients complicated by CAM at 27 (A and D), 28 (B and $\mathbf{E}$ ), and 29 (C and $\mathbf{F}$ ) weeks of gestation. A-C: The sections were immunostained with anti-IL- 6 antibody. D-F: Serial sections were immunostained with antiphosphorylated IKK antibody. Arrows indicate positive-stained cells (diaminobenzidine; brown). G: Negative control by nonimmune sera. H: Wilms' tumor was chosen to show $p-I K K \alpha / \beta$-positive staining. I: Number of IKK-phosphorylated cells (black bars) in amnions (am) per field in IL-6-expressing cells (white bars) in control and CAM-complicated placentas. Five representative images of amnions were randomly taken in each case. Each bar represents the means \pm SD (I). $n=3$ (I, control and CAM-complicated placentas). ${ }^{* * *} P<0.001$ versus control. Scale bar $=50 \mu \mathrm{m}(\mathbf{A}-\mathbf{H})$. Original magnification, $\times 200(\mathbf{A}-\mathbf{H})$. measured and normalized to a reference spot using Image Lab software version 2.0.1 (BioRad, Hercules, CA).

\section{Statistical Analysis}

JMP version 10.0.2 (SAS Institute Japan Ltd, Tokyo, Japan) was used for statistical analyses. All data were expressed as means $\pm \mathrm{SD}$. Differences were analyzed using the $U$ test or Pearson's $\chi^{2}$ test. Differences were considered statistically significant at $P<0.05$.

\section{Results}

\section{IL-6 Is Strongly Expressed in Amniotic Mesenchyme in CAM-Complicated Placentas, and Its Expression Increases Compared with Control Subjects}

First, to examine which cells mainly produce IL-6 in placentas complicated by CAM, immunohistochemical analyses were performed. Placental tissue sections from patients with severe CAM $(n=8)$ and normal-term subjects as control $(n=9)$ were immunostained for IL-6. The clinical characteristics of the patients are summarized in Table 1. Among eight patients with CAM-complicated PTDs, four delivered vaginally and four underwent cesarean sections. The mean gestational ages of CAM-complicated PTDs were 29.5 weeks. Representative images from CAM-complicated placentas at 28 and 29 weeks of gestation are shown in Figure 1. At amnions, IL-6-positive staining was seen mainly in mesenchymal cells rather than epithelial cells (Figure 1, A and C). IL-6 was also seen in villous mesenchymal cells and decidua (Figure 1, B and D), as previously reported. ${ }^{15}$ Fewer IL-6-positive cells were seen in normal-term placenta at 38 weeks of gestation (Figure 1, E and F). Negative control by nonimmune sera and Wilms' tumor as positive control for IL-6 staining are shown (Figure 1, G and $\mathrm{H}$ ), respectively. Because it is well established that amnions are a potent source of cytokine production, ${ }^{31}$ in this study, we focused on amnions as a source of IL-6 production, which is involved in inflammation-induced preterm birth. Five representative images of amnions were taken randomly, and the number of IL-6-expressing cells per field $(\times 200)$ was counted. A significantly higher number of IL-6-expressing mesenchymal cells was found in CAMcomplicated placentas $(n=8)$ than in control subjects $(n=9)(17 \pm 5$ versus $6 \pm 3 ; P<0.001)$ (Figure $1 \mathrm{I})$. These immunohistochemical findings indicated that the number of amniotic mesenchymal cells producing IL-6 increased in response to bacterial infection, suggesting the involvement of IL-6 derived from these cells in the pathogenesis of infection-related PTD.

\section{Amniotic Mesenchymal Cells Producing IL- 6 Are NF- $\kappa$ B Activated}

$\mathrm{NF}-\kappa \mathrm{B}$ is one of the most important regulators of proinflammatory gene expression. The activation of this pathway, followed by the consequent induction of IL-6 expression, depends specifically on the phosphorylation of IKK $\beta .^{18}$ Thus, serial cross sections of placental tissues obtained from patients complicated by CAM ( 27 to 29 weeks of gestation, $n=3$ ) (Figure 2, A-F) were subsequently immunostained for $\mathrm{p}-\mathrm{IKK} \alpha / \beta$ to confirm whether IL- 6 - producing cells were IKK-phosphorylated. For this purpose, the sections were immunostained with anti-IL-6 antibody (Figure 2, A-C), and the serial sections were immunostained with antiphosphorylated IKK antibody (Figure 2, D-F). Negative 

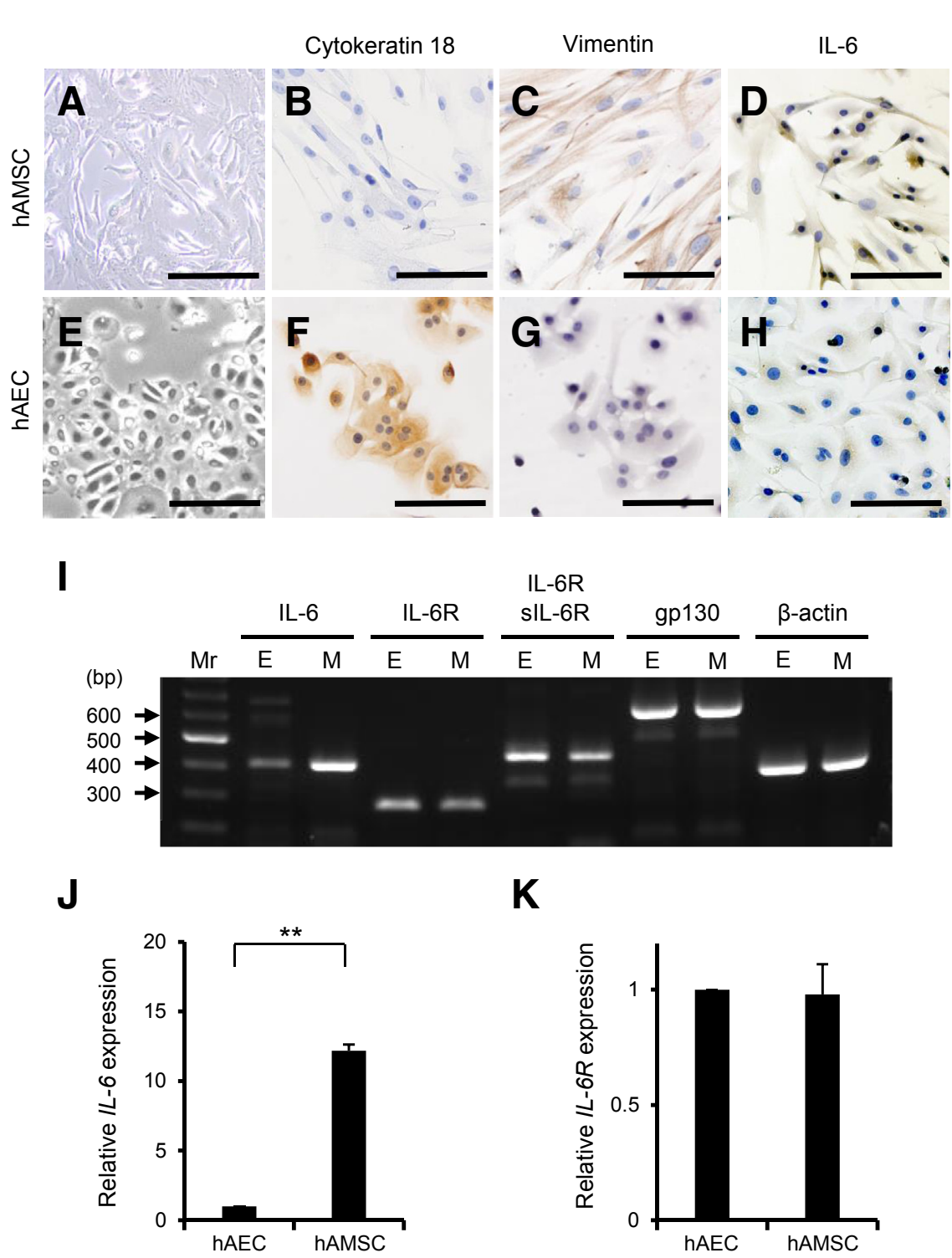

Figure 3 IL-6 is strongly expressed in human primary amniotic mesenchymal stromal cells (hAMSCs) rather than human primary amniotic epithelial cells (hAECs). The isolation of hAMSCs (A) and hAECs (E). hAMSCs display a fibroblast-like morphology, whereas hAECs display a cobble-stonelike morphology. B and C: Immunohistochemical analyses of hAMSCs. Cytokeratin 18-negative staining is seen in $\mathbf{B}$, whereas vimentin staining is positive in $\mathbf{C}$. $\mathbf{F}$ and $\mathbf{G}$ : Immunohistochemical analyses of hAECs. Cytokeratin 18-positive (F) and vimentinnegative (G) staining. $\mathbf{D}$ and $\mathbf{H}$ : Immunohistochemical analyses of IL- 6 in hAMSCS (D) and hAECS (H). I: RT-PCR of IL-6, IL-6 receptor (IL-6R), soluble IL-6R (sIL-6R), and gp130 from hAECs and hAMSCs. Blots are representative of three experiments. $\mathbf{J}$ and $\mathbf{K}$ : Realtime RT-PCR. Total RNA was collected from hAMSCs and subjected to RT-PCR. The $2^{-\Delta \Delta \mathrm{C}_{\mathrm{T}}}$ method was used to calculate the relative abundance of IL- 6 (J) and IL6 receptor (K) with respect to glyceraldehyde-3phosphate dehydrogenase expression. Each bar represents the means $\pm \mathrm{SD}(\mathbf{J}$ and $\mathbf{K}) . n=3(\mathbf{J}$ and $\mathbf{K})$. ${ }^{* * P}<0.01$. Scale bar $=100 \mu \mathrm{m}(\mathbf{A}-\mathbf{H})$. Original magnification, $\times 100(\mathbf{A}-\mathbf{H}) . \mathrm{E}$, hAECs; M, hAMSCs; Mr, marker.

control by nonimmune sera and Wilms' tumor as positive control for $\mathrm{p}-\mathrm{IKK} \alpha / \beta$ are shown (Figure $2, \mathrm{G}$ and $\mathrm{H}$ ), respectively. IL-6-expressing cells in amniotic mesenchyme were IKK phosphorylated in CAM-complicated placentas. To investigate whether the number of mesenchymal cells that IKK phosphorylated increased in CAMcomplicated placentas, control subjects (normal-term placentas, $n=3$ ) were subsequently immunostained for $\mathrm{p}$-IKK $\alpha / \beta$. Five representative images of amnions were randomly taken, and the number of $\mathrm{p}$-IKK $\alpha / \beta$-expressing cells per field $(\times 200)$ was counted. Control placentas had significantly fewer IKK phosphorylated mesenchymal cells than CAM-complicated placentas $(12 \pm 2.8$ versus $1.0 \pm 0.4 ; P<0.001$ ) (Figure 2I). Although $17 \%$ of IL-6-expressing cells were IKK phosphorylated in control placentas, $75 \%$ of IL-6-expressing cells were IKK phosphorylated in CAM-complicated placentas, suggesting that the activation of IKK, in response to inflammation, regulates IL-6 expression.

\section{IL-6 Is Strongly Expressed in hAMSCs Rather Than in hAECS}

Because mesenchymal cells in amnions strongly express IL-6, we collected primary hAMSCs as a potential source of IL-6 production in the placenta. hAMSCs displayed a fibroblastlike morphology and were cytokeratin-18 negative and vimentin positive (Figure 3, A-C), whereas hAECs displayed cobble-stone-like morphology and were cytokeratin-18 positive and vimentin negative (Figure 3, E-G), as previously reported. $^{27}$ Intense IL-6 staining was observed in hAMSCs compared with hAECs (Figure 3, D and H). RTPCR analysis revealed that hAMSCs expressed higher levels of mRNA for IL-6 (408 bp) than hAECs. Both hAMSCs and hAECs expressed membrane-bound IL-6R (280 and $441 \mathrm{bp)}$ and signal-transducing molecule gp130 (615 bp) to a similar extent (Figure 3I). Real-time RT-PCR confirmed that hAMSCs express significantly higher levels of IL-6 mRNA (12.2-fold) than hAECs 
A<smiles>O=C(Nc1cc(C(F)(F)F)ccc1C(F)(F)F)c1cc(Br)ccc1O</smiles>

D
B

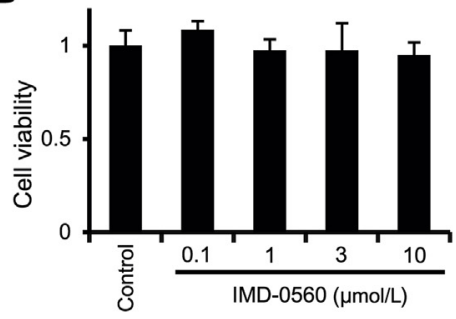

C

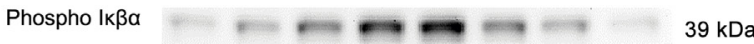

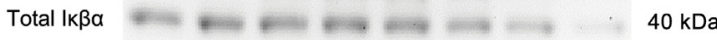

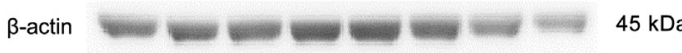

$\begin{array}{lllllllll}\text { TNFa (minutes) } & 0 & 5 & 10 & 15 & 30 & 60 & 90 & 120\end{array}$

$\mathbf{E}$
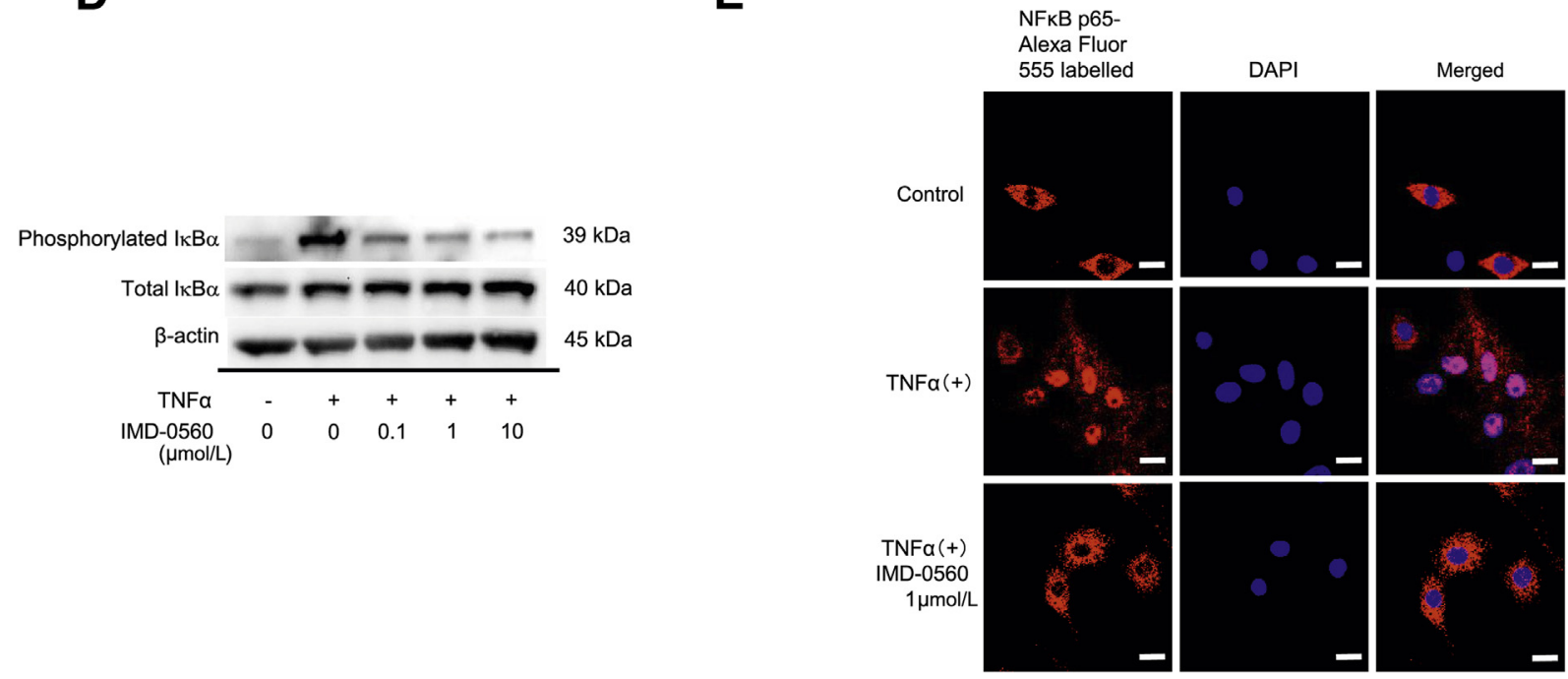

Figure 4 Effect of IMD-0560, a novel IKB kinase $\beta$ (IKK $\beta$ ) inhibitor, on human primary amniotic mesenchymal stromal cells (hAMSCs). A: Molecular formula of IMD-0560, N-(2,5-bis-trifluoromethylphenyl)-5-bromo-2-hydroxybenzamide (molecular weight, 428.1). B: In vitro cell viability assay. hAMSCs were incubated with various concentrations of IMD-0560 for 24 hours, and cell viability was assessed using a modified MTS assay. Culturing of hAMSCs with up to $10 \mu \mathrm{mol} / \mathrm{L}$ IMD-0560 had no effect on their viability. C: Western blot analysis. hAMSCs were pretreated with MG132 (proteasome inhibitor) for 2 hours and then stimulated with $10 \mathrm{ng} / \mathrm{mL}$ tumor necrosis factor (TNF)- $\alpha$ for the indicated times. Cell lysates were immunoblotted with anti-phosphorylated IKB antibody. The membranes were stripped and rehybridized with antibodies detecting IкB $\alpha$ or $\beta$-actin. D: hAMSCs were pretreated with various concentrations of IMD-0560 for 24 hours, $20 \mu \mathrm{mol} / \mathrm{L}$ of MG132 for 2 hours, and then stimulated with TNF- $\alpha$ for 30 minutes. Cell lysates were subjected to Western blot analysis. E: Representative confocal images of hAMSCs stimulated with $10 \mathrm{ng} / \mathrm{mL} \mathrm{TNF}-\alpha(+)$ (30 minutes) with or without pretreatment of $1 \mu \mathrm{mol} / \mathrm{L} \mathrm{IMD-0560}$ are shown. Cells were immunostained with Alexa Fluor 555-labeled NF- $\kappa B$ p65 (red). In controls [top panels; dimethyl sulfoxide, TNF- $\alpha(-)$ ] NF- $\kappa B$ is dominantly located in the cytoplasm. TNF- $\alpha$ stimulation (middle panels) induces the nuclear translocation of NF- $\kappa B$ p65. The pretreatment of IMD-0560 inhibits NF- $\kappa B$ nuclear translocation induced by TNF- $\alpha$ (bottom panels). Data represent means \pm SEM (B). $n=5$ from triplicate independent experiments (B). Scale bar $=20 \mu \mathrm{m}(\mathbf{E})$.

(Figure 3J), whereas no significant differences were observed between IL-6R mRNA levels (Figure 3K).

\section{Inflammation-Induced NF- $\kappa$ B Activation Is Inhibited by IMD-0560 in hAMSCS}

Because IKK phosphorylation correlated with IL-6 expression in clinical samples, we were encouraged to analyze the effects of a novel IKK $\beta$ inhibitor, IMD-0560, on IL-6 production from hAMSCs. IMD-0560, N-(2,5-bis-trifluoromethylphenyl)-5-bromo-2-hydroxybenzamide (molecular weight, 428.1) (Figure 4A), is a specific IKK $\beta$ inhibitor that blocks $\mathrm{I} \kappa \mathrm{B} \alpha$ phosphorylation, which has already been administered safely to humans in other clinical trials. First, we confirmed that up to $10 \mu \mathrm{mol} / \mathrm{L}$ of IMD-0560 did not affect cell viability of hAMSCs (Figure 4B). The effects of IMD0560 on NF- $\mathrm{BB}$ activation in hAMSCs were assessed by the phosphorylation of $\mathrm{I} \kappa \mathrm{B} \alpha$ and the nuclear translocation of its p65 subunit. TNF- $\alpha$ induced the phosphorylation of I $\mathrm{B} \alpha$ in a time-dependent manner, as shown in Figure $4 \mathrm{C}$, and reached the maximum at 30 minutes. IMD-0560 inhibited the phosphorylation of I $\mathrm{B} \alpha$ in a dose-dependent manner (Figure 4D). In immunofluorescence analyses, the p65 subunit was dominantly located in the cytoplasm in the control, and on TNF- $\alpha$ stimulation, p65 drastically translocated into nuclei. Pretreatment with $1 \mu \mathrm{mol} / \mathrm{L}$ IMD-0560 almost inhibited its nuclear translocation (Figure 4E). These data indicated that IMD-0560 efficiently inhibited NF- $\kappa \mathrm{B}$ activation in hAMSCs without impairing cell viability.

\section{IMD-0560 Inhibits IL-6 Production from Human Amniotic Mesenchymal Cells}

Next, to determine the therapeutic potential of IMD-0560, the effect of IMD-0560 on IL-6 production from hAMSCs was examined. After pretreatment with 1 to $3 \mu \mathrm{mol} / \mathrm{L}$ of IMD-0560 for 24 hours, IL-6 production was stimulated 

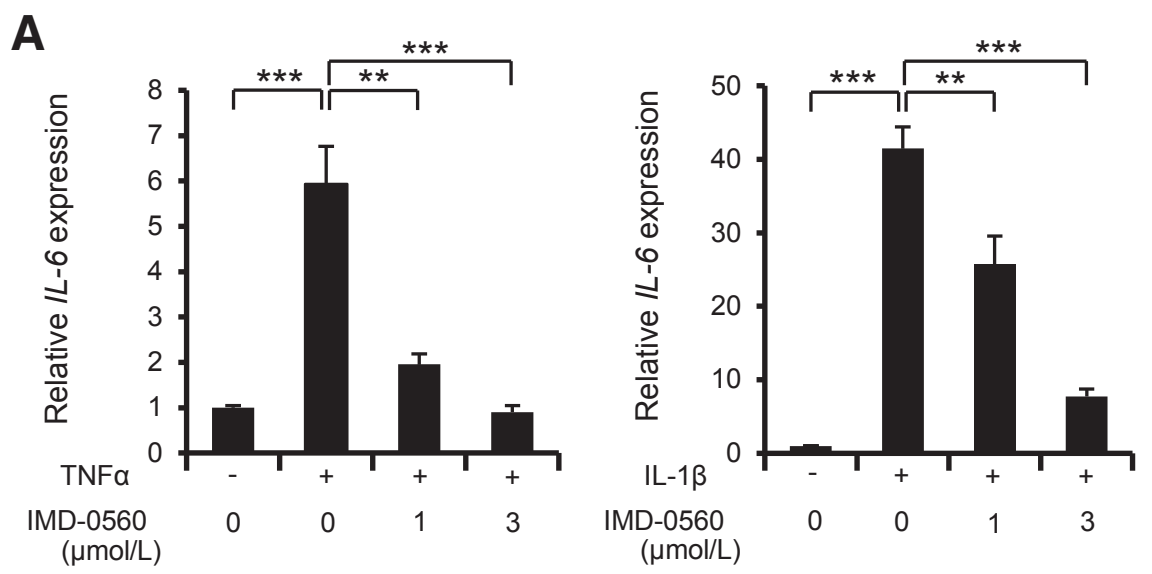

Figure 5 IMD-0560 inhibits IL-6 production from human primary amniotic mesenchymal stromal cells (hAMSCs) in response to tumor necrosis factor (TNF)- $\alpha$ or IL-1 $\beta$ stimuli. A: Real-time RT-PCR. A total of $5 \times 10^{5}$ of hAMSCs were cultured with $1 \mathrm{~mL}$ of $0.1 \%$ bovine serum albumin/Dulbecco's modified Eagle's medium with or without IMD-0560 for 24 hours and thereafter stimulated with $10 \mathrm{ng} / \mathrm{mL}$ TNF- $\alpha$ or $10 \mathrm{ng} / \mathrm{mL}$ IL- $1 \beta$ for 11 hours. Total RNA was collected from hAMSCs and subjected to RT-PCR. The $2^{-\Delta \Delta \mathrm{C}_{\mathrm{T}}}$ method was used to calculate the relative abundance of IL- 6 with respect to glyceraldehyde-3phosphate dehydrogenase expression. B: Conditioned media were collected, and the concentration of human IL-6 was measured by enzyme-linked immunosorbent assay. Data represent the means $\pm \mathrm{SD}(\mathbf{A}$ and $\mathbf{B}) . n=3(\mathbf{A}$ and $\mathbf{B}) .{ }^{*} P<0.01$ $* * * P<0.001$
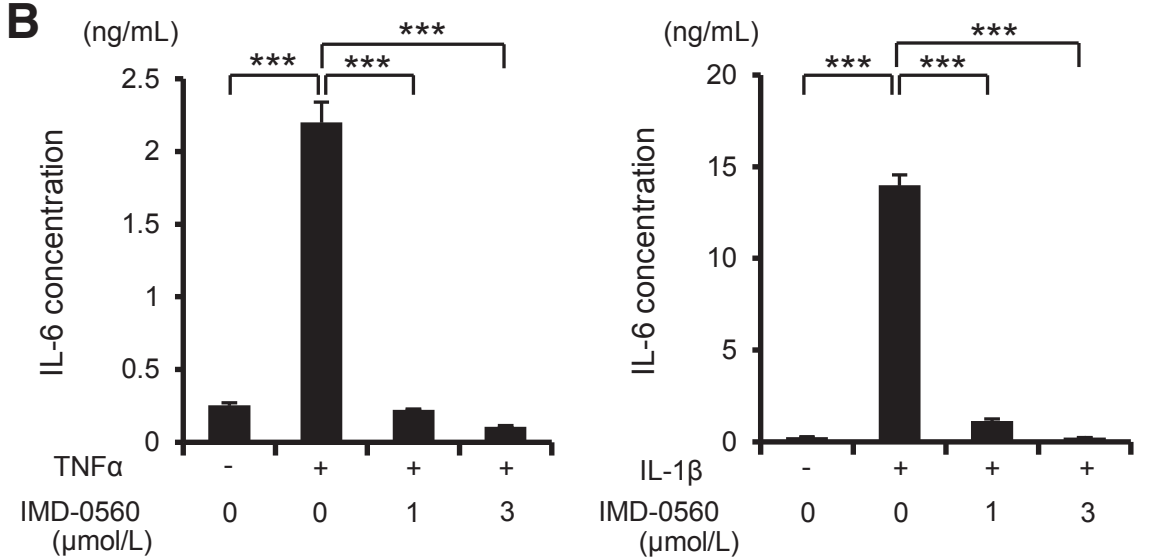

with TNF- $\alpha$ or IL- $1 \beta$. Although TNF- $\alpha$ or IL- $1 \beta$ drastically stimulated IL-6 production at both the mRNA level (TNF- $\alpha$, 5.9-fold; IL-1 $\beta$, 41.5-fold) (Figure 5A) and protein level (TNF- $\alpha, 2.2 \mathrm{ng} / \mathrm{mL} ; \quad \mathrm{IL}-1 \beta, 14 \mathrm{ng} / \mathrm{mL}$ ) (Figure 5B) compared with that in controls $(0.25 \mathrm{ng} / \mathrm{mL})$, IMD-0560 almost completely inhibited TNF- $\alpha-$ or IL- $1 \beta$-induced increases of IL-6 production in a dose-dependent manner, indicating that IMD-0560 can serve as a potent inhibitor of IL-6 production from hAMSCs.

\section{Vaginal Administration of IMD-0560 Successfully Prevents PTD in an LPS-Induced PTD Mouse Model}

Because IMD-0560 successfully inhibited IL-6 production from hAMSCs via the inhibition of IKK activation, we asked whether anticytokine therapy using this drug can prevent PTD in an LPS-induced PTD mouse model. C3H/ $\mathrm{HeN}$ female mice were pair-mated with B6D2F1 male mice to deliver preterm in response to low-dose LPS (double doses of $50 \mu \mathrm{g} / \mathrm{kg}$ at 3-hour intervals), as we and others have previously reported. ${ }^{15,30,32}$ LPS administration induced PTD reproducibly [12 of $12(100 \%)]$ without any apparent adverse effects on the pregnant mice. In light of future clinical application in humans, vaginal tablets containing IMD-0560 were prepared and administered to pregnant mice transvaginally. Treatment schedules are summarized in
Figure 6A. Initial dose-finding studies of IMD-0560 were performed. Three different doses $(15,30$, and $60 \mu \mathrm{g} / \mathrm{kg})$ of IMD-0560 were administered vaginally by two different frequencies (once and twice a day); $30 \mu \mathrm{g} / \mathrm{kg}$ of IMD-0560 administration twice a day appeared to prevent LPS-induced PTD most efficiently (Supplemental Figure S1). Therefore, we adopted $30 \mu \mathrm{g} / \mathrm{kg}$ of IMD-0560 administration twice daily in this study and found IMD-0560 prevented PTD by $45 \%$ (10 of 22), whereas all control mice delivered preterm with LPS administration [12 of $12(100 \%)](P<0.001)$ (Figure 6B). Accordingly, IMD-0560 treatment significantly prolonged the average gestational period (control, $16.5 \pm 0$ days; IMD-0560, $18.1 \pm 0.3$ days; $P<0.001$ ) (Figure 6C). IMD-0560 treatment without LPS injection did not cause a delay in the delivery date $(19.5 \pm 0.4$ days) (Figure $6 \mathrm{C})$. To address whether the direct inhibition of IL- 6 signaling prevents inflammation-induced PTD, anti-mouse IL-6R antibody, MR16-1, was treated. The treatment of this antibody showed a significantly lower rate of PTD $(50 \%$; four of eight delivered preterm) compared with control IgG (100\%; six of six delivered preterm) $(P<0.05)$ and showed similar results with IMD-0560 treatment (Figure 6B). It is well known that the progesterone receptor antagonist, RU486, causes noninfectious preterm labor in rodents. ${ }^{33}$ Thus, the effect of IMD-0560 was examined in RU486-induced PTD model mice. Although at a dose of $150 \mu \mathrm{g}$ of RU486, five of 
five mice delivered preterm, IMD-0560 did not show any preventive effects and all mice ( 5 of 5 ) treated delivered preterm (Figure 6C), indicating IMD-0560 is effective in inhibiting inflammation-related disorders.

Because IMD-0560 was effective in the prevention of LPS-induced PTD, the effects of IMD-0560 on IL-6 production were assessed using murine maternal serum. Serum IL-6 concentration was markedly increased 1 hour after LPS administration, and IMD-0560 treatment significantly inhibited the up-regulation of IL-6 concentration (LPS administration, $9.9 \mathrm{ng} / \mathrm{mL}$; LPS + IMD-0560, $2.3 \mathrm{ng} / \mathrm{mL}$; $P=0.0136$ ) (Figure 6D). IMD-0560 was treated vaginally to induce the maximum effect locally. Thus, murine uterine tissues were collected and IL-6 mRNA expression was assessed by real-time RT-PCR (Figure 6E). Although LPS administration drastically induced the up-regulation of IL-6 mRNA expression by 79.7-fold, IMD-0560 treatment robustly inhibited this up-regulation ( 8.5 fold, $P=0.0333$ ), indicating this drug works adequately at a local inflammatory site. Because NF- $\kappa \mathrm{B}$ signaling is known to activate several cytokines other than IL- $6,{ }^{34}$ the effect of IMD-0560 on cytokine production was assessed using a murine serum cytokine array (Figure 6F). The relative intensities of representative spots on the membranes were measured and normalized to reference spots (Figure $6 \mathrm{G}$ ). Figure $6 \mathrm{H}$ shows cytokine array panel used. LPS systemic administration induced the up-regulation of various cytokines, and IMD0560 inhibited not only IL- 6 expression but also that of other proinflammatory cytokines, as shown in Supplemental Table S1. Of these, in addition to IL-6, keratinocytederived protein chemokine (alias CXCL1), monocyte chemoattractant protein-1 (MCP-1; alias chemokine ligand 2), and macrophage inflammatory protein-2 (alias CXCL2) have been reported to be correlated with PTD. ${ }^{35}$ Thus, we further examined mRNA expressions of these cytokines in murine uterine tissues by real-time RT-PCR (Figure 6I). IMD-0560 treatment significantly suppressed all these mRNA expression levels (Figure 6I), suggesting that this novel IKK $\beta$ inhibitor has the potential to prevent inflammation-induced PTD by suppressing multiple related cytokines.

\section{Discussion}

PTD rates have continued to increase so far, even in many developed countries, ${ }^{36}$ and it remains the leading cause of infant morbidity and mortality worldwide. Thus, the molecular mechanisms controlling labor must be better understood so that therapies to retard PTD can be optimally designed. In the present study, we provide evidence that IL-6 is produced mainly in amniotic mesenchymal stromal cells in response to inflammation and found that IL-6-producing cells are IKKphosphorylated. Furthermore, we showed that a novel IKK $\beta$ inhibitor, IMD-0560, inhibited LPS-induced PTD through the suppression of several inflammatory cytokines, including IL-6. Although various studies have shown that inflammatory cytokines, such as IL-1 $\beta$, IL-6, or IL-8, play indispensable roles in parturition, including PTD, no anticytokine therapies have been used in the clinical setting. Our data provide a prerequisite step before an IKK $\beta$ inhibitor can be attempted for the prevention of PTD in human pregnancy.

Although the etiology of PTD is complex, many previous studies have shown that the expression of inflammatory cytokines induced by infection is one of the most critical underlying causes. Among these, elevated expression of IL-6 has been observed in the amniotic fluids and in cervicovaginal fluids, which is strongly associated with spontaneous preterm birth. ${ }^{16}$ Moreover, an elevated IL-6 level in vaginal fluid samples of women at mid-trimester (16 to 27 weeks of gestation) was associated with increased rates of spontaneous PTD at $<35$ weeks and with PTD complicated by CAM, and had the greatest sensitivity for detecting these two PTD subtypes. ${ }^{37}$ Thus, targeting IL-6 signaling appears to be one of the most reasonable approaches for the treatment of PTD. The specific cell lineages producing IL- 6 during term or preterm labor are not well defined, whereas amnion, choriodecidua, and infiltrating leukocytes in the fetal membrane, placentas, and myometrium are implicated as a source of IL-6 production in placentas, respectively. ${ }^{15,31,35}$ Using immunohistochemical analyses (Figure 1), we showed that amniotic mesenchymal cells expressed IL-6 strongly in all CAMcomplicated placentas, suggesting that these cells are one of the potent sources of IL- 6 production in infectious placentas.

Using serial sections of CAM-complicated placentas, we showed that amniotic mesenchymal cells expressing IL-6 are IKK-phosphorylated. Furthermore, we revealed that a novel IKK $\beta$ inhibitor, IMD-0560, successfully suppressed IL-6 production from amniotic mesenchymal cells, which led to the inhibition of LPS-induced PTD in model mice. Because it is well established that NF- $\mathrm{KB}$ activation is a major regulator of IL-6 production, targeting NF- $\kappa \mathrm{B}$ activation is likely to be feasible as a potential molecular therapy against inflammationinduced PTD, considering the pivotal roles of this cytokine in its etiology. Indeed, several inhibitors of NF- $\mathrm{BB}$ signaling have been attempted for the treatment of PTD preclinically. ${ }^{38}$ Condon et $\mathrm{al}^{39}$ reported that intra-amniotic injection of NF- $\mathrm{\kappa B}$ inhibitor peptide, SN50, delayed the onset of labor in mice. Pirianov et $\mathrm{al}^{40}$ reported that the intrauterine injection of 15-deoxy- $\Delta 12,14$-prostaglandin $\mathrm{J} 2$, an anti-inflammatory prostaglandin, delayed LPS-induced preterm labor and significantly increased pup survival in mice, accompanied by the inhibition of several inflammatory protein syntheses, including myometrial NF- $\kappa$ B. Sulfasalazine, a salicylate drug that blocks NF- $\kappa \mathrm{B}$ activation by directly inhibiting IKK kinases, ${ }^{41}$ is well tolerated and has been approved for use in pregnancy, with no discernible increase in risk of fetal congenital defects, morbidity, or mortality. ${ }^{38}$ Nath et al ${ }^{42}$ reported that sulfasalazine administration subcutaneously reduces rates of PTD in mice infected with $10^{4}$ colonyforming units of $E$. coli but does not improve pup survival. $N$-acetylcysteine is a non-specific free radical scavenger and works as a NF- $\kappa \mathrm{B}$ inhibitor. Clinically, a 
randomized, double-blind, placebo-controlled trial with 280 high-risk women with bacterial vaginosis and prior PTD was performed, ${ }^{43}$ and $N$-acetylcysteine oral administration resulted in significantly fewer PTDs, an increase in birth weight, and a reduction in neonatal morbidity and mortality. However, these clinical findings have not yet been replicated in other studies, and $\mathrm{N}$-acetylcysteine has not progressed into clinical use so far. ${ }^{38}$ The

A

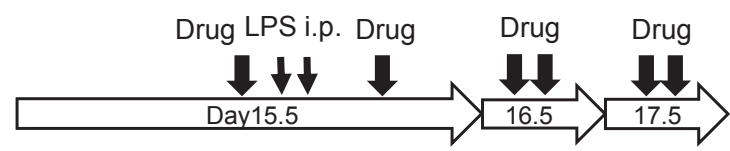

B

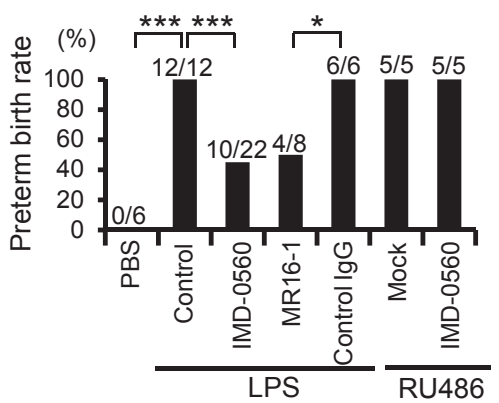

D

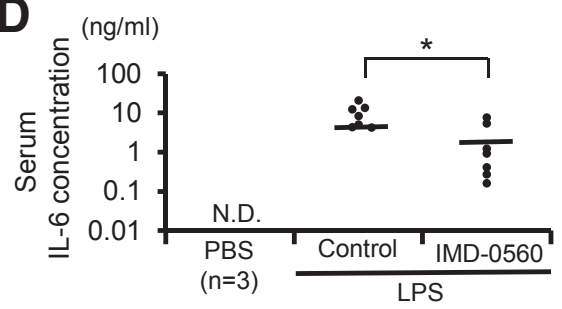

$\mathbf{F}$

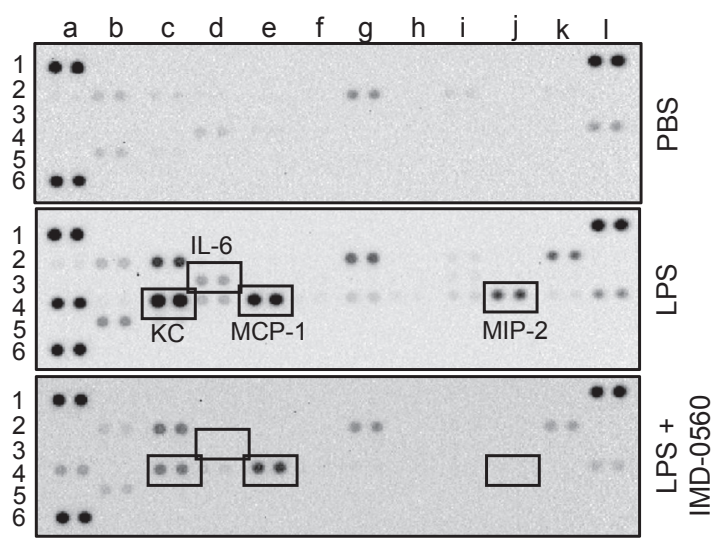

$\mathbf{C}_{\text {(Days) }} \overbrace{}^{* * * *}$
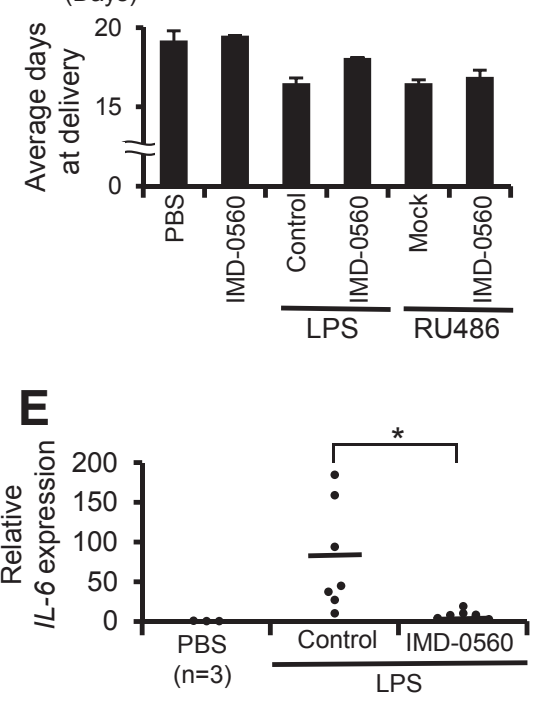

G

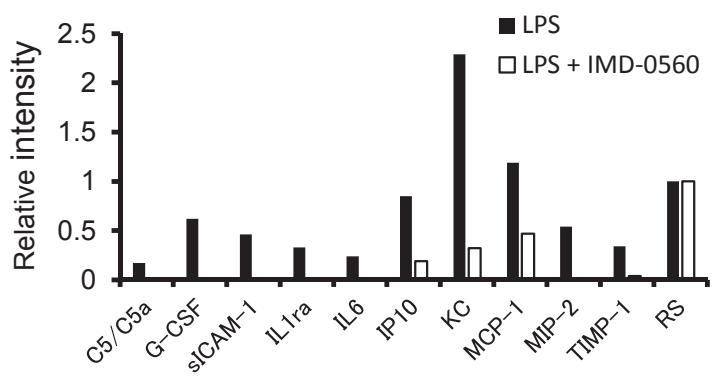

H

\begin{tabular}{|c|c|c|c|c|c|c|c|c|c|c|c|c|}
\hline & a & $b$ & C & d & e & $f$ & $\mathrm{~g}$ & $\mathrm{~h}$ & i & $j$ & $\mathrm{k}$ & I \\
\hline 1 & RS & Blank & Blank & Blank & Blank & Blank & Blank & Blank & Blank & Blank & Blank & RS \\
\hline 2 & CXCL13 & C5/C5a & G-CSF & GM-CSF & $\mathrm{CCL} 1$ & CCL11 & sICAM-1 & IFN-y & $\mathrm{IL}-1 \alpha$ & $\mathrm{IL}-1 \beta$ & IL-1ra & IL-2 \\
\hline 3 & IL-3 & IL-4 & IL-5 & IL-6 & IL-7 & IL-10 & IL-13 & IL-12p70 & IL-16 & IL-17 & IL-23 & IL-27 \\
\hline 4 & IP-10 & CXCL11 & $\mathrm{KC}$ & M-CSF & MCP-1 & MCP-5 & CXCL9 & MIP-1a & MIP-1 $\beta$ & MIP-2 & RANTES & CXCL12 \\
\hline 5 & CCL17 & TIMP-1 & TNF- $\alpha$ & TREM-1 & Blank & Blank & Blank & Blank & Blank & Blank & Blank & Blank \\
\hline 6 & $\mathrm{RS}$ & Blank & Blank & Blank & Blank & Blank & Blank & Blank & Blank & Blank & Blank & NegC \\
\hline
\end{tabular}

I

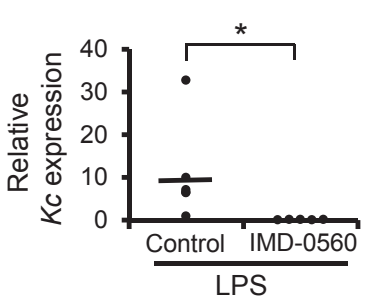

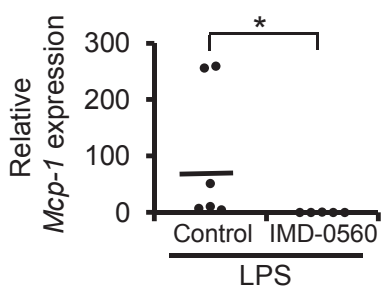

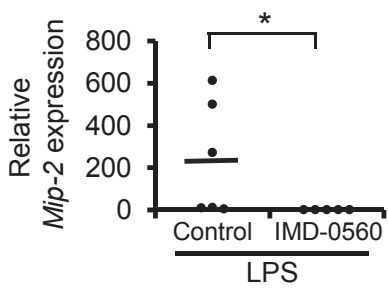


indispensable roles played by NF- $\kappa \mathrm{B}$ in many biological processes raise the concern that a complete shutdown of this pathway would have significant detrimental effects on normal cellular function. More specifically, maternal administration might suppress $\mathrm{NF}-\kappa \mathrm{B}-$ dependent innate immune defenses, increasing susceptibility to infections, and lead to possible non-specific fetal toxicities. Two IкB kinases, IKK $\alpha$ and IKK $\beta$, have been described, and it is known that they have nonequivalent functions and that activation of IKK $\beta$, rather than IKK $\alpha$, participates in the primary pathway by which proinflammatory stimuli activate NF-кB. ${ }^{18}$ Thus, selectively targeting only IKK $\beta$ activity can be of greater therapeutic value for clinical use. ${ }^{44}$ Some specific IKK $\beta$ inhibitors have been tested in vitro. [5-(p-Fluorophenyl)-2-ureido] thiopene-3-caboxamide and parthenolide inhibited LPS-induced inflammation and NF$\kappa \mathrm{B}$ nuclear translocation in primary choriodecidual cells. ${ }^{45}$ The authors reported that unlike sulfasalazine no impairment of cell viability or apoptosis was detected, suggesting safer profiles of the IKK $\beta$ inhibitor. Moreover, in 2015, using an ovine model of LPS-induced CAM, intraamniotic administration of [5-(p-fluorophenyl)-2-ureido] thiopene-3-caboxamide was found to inhibit not only the accumulation of prostaglandin $E_{2}$ in amniotic fluid but the leukocytosis of the fetal membranes, although at the doses used, no significant reduction of IL-6 production was reported and preventive effects on PTD were not evaluated. ${ }^{46}$ Thus, to the best of our knowledge, our report is the first to demonstrate the preventive effects of a IKK $\beta$ inhibitor on PTD by suppressing IL-6 production from placental tissues in vivo. IMD-0560 is a synthetic low-molecular-weight compound that specifically inhibits IKK $\beta$, inducing the inhibition of NF- $\mathrm{B}$ activation only in inflammatory conditions, and it has been shown that this drug does not inhibit other kinases, proteases, or proteasome-related immune responses. ${ }^{21}$ A phase 1 study has been completed using IMD-2560, a prodrug of IMD-0560, for rheumatoid arthritis, and sufficient safety and tolerability have been adequately confirmed. ${ }^{22}$ Thus, pharmacodynamic profiles of IMD-0560 appear promising, and the lack of toxicity in vitro and in vivo suggests that this drug could be a potential therapeutic approach for the treatment of PTD.

In inflammation-induced PTD model mice, we showed that IMD-0560 successfully inhibited the expression levels not only of IL-6, but also of several cytokines, such as keratinocyte-derived protein chemokine/CXCL1, MCP-1/ chemokine ligand 2 , and macrophage inflammatory protein2/CXCL2, in murine uteri. In mouse, the genes encoding IL-8 and its receptor, CXCR1, have been deleted, and murine keratinocyte-derived protein chemokine or macrophage inflammatory protein-2 seems to be the functional homolog of IL-8 because they share the extracellular loop reactive motif (Glu-Leu-Arg) for the chemoattractant properties of IL-8 family members. ${ }^{47} \mathrm{IL}-8$ is well-known as one of the most potent neutrophil chemoattractants and activators, and CAM is associated with intense neutrophil infiltration of the fetal membranes. ${ }^{48}$ Thereafter, activated neutrophils can also be a rich source of proinflammatory cytokines and prostaglandins, which further contribute to the onset of PTD. Indeed, amniotic fluid IL-8 has been proved to be associated with the occurrence of preterm premature rupture of membranes and PTD. ${ }^{49}$ Several human studies have suggested a unique role for MCP1 in PTD. For instance, Jacobsson et $\mathrm{al}^{50}$ reported finding elevated MCP-1 in the cervix of women having PTD associated with intra-amniotic infection. Esplin et $\mathrm{a}^{51}$ described significantly elevated MCP-1 levels in the amniotic fluid of women having PTD, supporting an important role for MCP-1 during preterm labor. Given the potentially important roles for these cytokines during PTD, the fact that IMD-0560 inhibited the levels of these cytokines in vivo strengthened the therapeutic value of this drug for the treatment of PTD.

Limitations of the present study include that LPS was administered systemically, which could not accurately mimic the condition of CAM with ascending infection, yet it is an established model of inflammation-induced PTD. Although LPS only represents Gram-negative bacterial infection, the commonly associated organisms with amniotic fluid infection

\footnotetext{
Figure 6 Effects of IMD-0560, a novel IKB kinase $\beta$ (IKK $\beta$ ) on lipopolysaccharide (LPS)-induced preterm delivery in mice. A: Schedule of in vivo experiments. Pregnant C3H/HeN females at 15.5 days of gestation were given $50 \mu \mathrm{g} / \mathrm{kg}$ LPS twice i.p., at 3-hour intervals. IMD-0560 (30 mg/kg) was delivered twice a day vaginally from 15.5 days of gestation. Preterm delivery was defined as delivery before 18.5 days of gestation. B: Preterm delivery rate in each group. Numbers of mice that delivered preterm in each group are presented. IMD-0560 treatment suppressed LPS-induced preterm delivery; however, it did not affect RU486-induced preterm birth. MR16-1 (12 mg/kg) was given to pregnant C3H/HeN females at 14.5 days of gestation. C: Average gestational days at delivery in each group. D: Effects of IMD0560 on murine maternal serum IL-6 concentration. Enzyme-linked immunosorbent assay: Each plot represents every value 1 hour after the second LPS treatment. E: Effects of IMD-0560 on the murine uterus IL-6 mRNA expression level. Real-time PCR: Total RNA was extracted from the murine uterus 1 hour after the second LPS treatment. Each plot represents individual relative expression value with respect to phosphate-buffered saline (PBS) treatment. The $2^{-\Delta \Delta C_{T}}$ method was used to calculate the relative abundance of IL-6 with respect to glyceraldehyde-3-phosphate dehydrogenase (Gapdh). F: Murine serum cytokine array. The array key represents the location of each antibody in duplicate on the membrane. Serum collected from PBS-treated mouse (top panel), LPS-treated mouse (middle panel), and LPS-treated mouse after the IMD-0560 administration (bottom panel). G: Relative intensity of each spot on the membranes was measured and normalized to the reference spot (RS). Representative cytokines suppressed by IMD-0560 are listed on the graph. H: Cytokine array panel. I: Real-time RT-PCR. Total RNA was extracted from murine uterus 1 hour after the second LPS treatment. Relative expression values normalized to Gapdh are shown. Data represent the means \pm SD (C) or the means (D, E, and I). ${ }^{*} P<0.05,{ }^{* *} P<0.001$. CCL, chemokine (C-C motif) ligand; $\mathrm{CXCL}$, chemokine (C-X-C Motif) ligand; G-CSF, granulocyte colony-stimulating factor; GM-CSF, granulocyte macrophage colony-stimulating factor; IP-10, interferon inducible protein 1; KC, keratinocyte-derived protein chemokine; MCP-1, monocyte chemoattractant protein-1; MCP-5, monocyte chemoattractant protein-5; M-CSF, macrophage colony-stimulating factor; MIP-1 $\alpha$, macrophage inflammatory protein-1 $\alpha$; MIP- $1 \beta$, macrophage inflammatory protein-1 $\beta$; MIP-2, macrophage inflammatory protein-2; ND, not detected; NegC, negative control; RANTES, regulated on activation normal T-cell expressed and secreted; sICAM-1, soluble intercellular adhesion molecule 1; TIMP-1, tissue inhibitor of metalloproteinases; TNF- $\alpha$, tumor necrosis factor- $\alpha$; TREM- 1 , triggering receptor expressed on myeloid cells.
} 
include Gram-positive bacteria, such as Peptostreptococcus, Enterococcus, and Streptococcus species. ${ }^{52}$ Furthermore, viruses, even fungi, can be implicated in inflammation-induced PTD. ${ }^{52}$ Indeed, several studies have shown that PTD can be induced in animal models by pathogen-derived Toll-like receptor ligands, which mediate viral infection. ${ }^{53,54}$ Further research would be needed to clarify the potential of targeting $\mathrm{NF}-\mathrm{KB}$ signaling in these other inflammation-induced PTD model mice. IMD-0560 had a significant effect on the number of dams giving birth to at least one live pup [control, $0 \%$ ( 0 of 12); IMD-0560, 45\% (10 of 22); $P<0.05$ ]; however, we did not evaluate neurodevelopmental and growth outcomes of pups - the ultimate goal of PTD is improved fetal outcomes, not only the prevention of prematurity. Fetal inflammation seems to be involved in the pathophysiology of a variety of neonatal morbidities associated with PTD, including necrotizing enterocolitis, periventricular leukomalacia, and cerebral palsy. ${ }^{55}$ Further elucidation would be needed to assess the feasibility and safety of IMD-0560 against fetuses in utero, although there have been no published studies on the teratogenic effects of IKK inhibitors at present. ${ }^{38}$

In conclusion, our study revealed that IL-6 is strongly expressed in amniotic mesenchymal stromal cells in CAMcomplicated placentas, and that its expression increases in response to infection. Also, NF- $\kappa \mathrm{B}$ activity increased in IL-6-expressing cells. Vaginal administration of IMD-0560 successfully prevented PTD in an inflammation-induced PTD mouse model not only by inhibiting IL-6 production but also that of other related cytokines from murine uteri. Considering the potential future clinical application in humans, prophylactic treatment of asymptomatic high-risk women in mid-trimester with high levels of cervicovaginal IL-6 might be an attractive treatment strategy because it theoretically offers the means to prevent the activation of myometrial contractions but also distally inhibit associated inflammation or other causal pathways of neonatal injuries. In this regard, anticytokine therapy with the selective inhibition of NF- $\mathrm{BB}$ activation using IKK $\beta$ inhibitor might hold a significant advantage over other conventional pharmacological approaches for the prevention of PTD and the improvement of neonatal outcomes.

\section{Acknowledgments}

We thank Ryoichi Tomita and Ayako Okamura for their technical assistance and Mami Morikawa for her secretarial assistance.

\section{Supplemental Data}

Supplemental material for this article can be found at http://dx.doi.org/10.1016/j.ajpath.2015.11.004.

\section{References}

1. Liu L, Johnson HL, Cousens S, Perin J, Scott S, Lawn JE, Rudan I, Campbell H, Cibulskis R, Li M, Mathers C, Black RE: Child Health
Epidemiology Reference Group of WHO and UNICEF. Lancet 2012 , 379:2151-2161

2. Goldenberg RL, Culhane JF, Iams JD, Romero R: Epidemiology and causes of preterm birth. Lancet 2008, 371:75-84

3. McCormick MC: The contribution of low birth weight to infant mortality and childhood morbidity. N Engl J Med 1985, 312:82-90

4. Simhan HN, Caritis SN: Prevention of preterm delivery. N Engl J Med 2007, 357:477-487

5. Yoon BH, Romero R, Moon JB, Shim SS, Kim M, Kim G, Jun JK: Clinical significance of intra-amniotic inflammation in patients with preterm labor and intact membranes. Am J Obstet Gynecol 2001, 185: $1130-1136$

6. Lim R, Morwood CJ, Barker G, Lappas M: Effect of silibinin in reducing inflammatory pathways in in vitro and in vivo models of infection-induced preterm birth. PLoS One 2014, 9:e92505

7. Gomez-Lopez N, Laresgoiti-Servitje E, Olson DM, EstradaGutiérrez G, Vadillo-Ortega F: The role of chemokines in term and premature rupture of the fetal membranes: a review. Biol Reprod 2010, 82:809-814

8. Arcuri F, Toti P, Buchwalder L, Casciaro A, Cintorino M, Schatz F, Rybalov B, Lockwood CJ: Mechanisms of leukocyte accumulation and activation in chorioamnionitis: interleukin 1 beta and tumor necrosis factor alpha enhance colony stimulating factor 2 expression in term decidua. Reprod Sci 2009, 16: $453-461$

9. Kaukola T, Herva R, Perhomaa M, Pääkkö E, Kingsmore S, Vainionpää L, Hallman M: Population cohort associating chorioamnionitis, cord inflammatory cytokines and neurologic outcome in very preterm, extremely low birth weight infants. Pediatr Res 2006, $59: 478-483$

10. Pang Y, Fan LW, Zheng B, Cai Z, Rhodes PG: Role of interleukin-6 in lipopolysaccharide-induced brain injury and behavioral dysfunction in neonatal rats. Neuroscience 2006, 141:745-755

11. Shahshahan Z, Hashemi L: Maternal serum cytokines in the prediction of preterm labor and response to tocolytic therapy in preterm labor women. Adv Biomed Res 2014, 3:126

12. Sood BG, Rambhatla A, Thomas R, Chen X: Decreased hazard of necrotizing enterocolitis in preterm neonates receiving red cell transfusions. J Matern Fetal Neonatal Med 2015, 3:1-8

13. Cobo T, Palacio M, Navarro-Sastre A, Ribes A, Bosch J, Filella X, Gratacós E: Predictive value of combined amniotic fluid proteomic biomarkers and interleukin-6 in preterm labor with intact membranes. Am J Obstet Gynecol 2009, 200:499e1-499e6

14. Nishimoto N, Hashimoto J, Miyasaka N, Yamamoto K, Kawai S, Takeuchi T, Murata N, van der Heijde D, Kishimoto T: Study of active controlled monotherapy used for rheumatoid arthritis, an IL-6 inhibitor (SAMURAI): evidence of clinical and radiographic benefit from an $\mathrm{x}$ ray reader-blinded randomised controlled trial of tocilizumab. Ann Rheum Dis 2007, 66:1162-1167

15. Wakabayashi A, Sawada K, Nakayama M, Toda A, Kimoto A, Mabuchi S, Kinose Y, Nakamura K, Takahashi K, Kurachi H, Kimura T: Targeting interleukin-6 receptor inhibits preterm delivery induced by inflammation. Mol Hum Reprod 2013, 19:718-726

16. Wei SQ, Fraser W, Luo ZC: Inflammatory cytokines and spontaneous preterm birth in asymptomatic women: a systematic review. Obstet Gynecol 2010, 116:393-401

17. Libermann TA, Baltimore D: Activation of interleukin-6 gene expression through the NF-kappa B transcription factor. Mol Cell Biol 1990, 10:2327-2334

18. Tak PP, Firestein GS: NF-kappaB: a key role in inflammatory diseases. J Clin Invest 2001, 107:7-11

19. Kinose Y, Sawada K, Makino H, Ogura T, Mizuno T, Suzuki N, Fujikawa T, Morii E, Nakamura K, Sawada I, Toda A, Hashimoto K, Isobe A, Mabuchi S, Ohta T, Itai A, Morishige K, Kurachi H, Kimura T: IKK $\beta$ regulates VEGF expression and is a potential therapeutic target for ovarian cancer as an antiangiogenic treatment. Mol Cancer Ther 2015, 14:909-919 
20. Ghosh S, Hayden MS: Celebrating 25 years of NF-кB research. Immunol Rev 2012, 246:5-13

21. Suzuki J, Ogawa M, Muto S, Itai A, Isobe M, Hirata Y, Nagai R: Novel IkB kinase inhibitors for treatment of nuclear factor-kB-related diseases. Expert Opin Investig Drugs 2011, 20:395-405

22. Young ER: IKK $\beta$ as a therapeutic intervention point diseases related to inflammation. Edited by Levin JI, Laufer S. Anti-Inflammatory Drug Discovery. Cambridge, UK: RSC Publishing, 2012, pp 255-296

23. Tada Y, Kokabu S, Sugiyama G, Nakatomi C, Aoki K, Fukushima H, Osawa K, Sugamori Y, Ohya K, Okamoto M, Fujikawa T, Itai A, Matsuo K, Watanabe S, Jimi E: The novel IкB kinase $\beta$ inhibitor IMD-0560 prevents bone invasion by oral squamous cell carcinoma. Oncotarget 2014, 5:12317-12330

24. Okazaki Y, Sawada T, Nagatani K, Komagata Y, Inoue T, Muto S, Itai $\mathrm{A}$, Yamamoto $\mathrm{K}$ : Effect of nuclear factor-kappaB inhibition on rheumatoid fibroblast-like synoviocytes and collagen induced arthritis. J Rheumatol 2005, 32:1440-1447

25. Gibbs RS, Blanco JD, St Clair PJ, Castaneda YS: Quantitative bacteriology of amniotic fluid from women with clinical intraamniotic infection at term. J Infect Dis 1982, 145:1-8

26. Blanc WA: Pathology of the placenta, membranes, and umbilical cord in bacterial, fungal, and viral infections in man. Monogr Pathol 1981, 22:67-132

27. Parolini O, Alviano F, Bagnara GP, Bilic G, Bühring HJ, Evangelista M, Hennerbichler S, Liu B, Magatti M, Mao N, Miki T, Marongiu F, Nakajima H, Nikaido T, Portmann-Lanz CB, Sankar V, Soncini M, Stadler G, Surbek D, Takahashi TA, Redl H, Sakuragawa N, Wolbank S, Zeisberger S, Zisch A, Strom SC: Concise review: isolation and characterization of cells from human term placenta: outcome of the first international Workshop on Placenta Derived Stem Cells. Stem Cells 2008, 26:300-311

28. Nakanishi H, Yoshioka K, Joyama S, Araki N, Myoui A, Ishiguro S, Ueda T, Yoshikawa H, Itoh K: Interleukin-6/soluble interleukin-6 receptor signaling attenuates proliferation and invasion, and induces morphological changes of a newly established pleomorphic malignant fibrous histiocytoma cell line. Am J Pathol 2004, 165:471-480

29. Livak KJ, Schmittgen TD: Analysis of relative gene expression data using real-time quantitative PCR and the 2(-Delta Delta C(T)) Method. Methods 2001, 25:402-408

30. Kaga N, Katsuki Y, Obata M, Shibutani Y: Repeated administration of low-dose lipopolysaccharide induces preterm delivery in mice: a model for human preterm parturition and for assessment of the therapeutic ability of drugs against preterm delivery. Am J Obstet Gynecol 1996, 174:754-759

31. Keelan JA, Sato T, Mitchell MD: Interleukin (IL)-6 and IL-8 production by human amnion: regulation by cytokines, growth factors, glucocorticoids, phorbol esters, and bacterial lipopolysaccharide. Biol Reprod 1997, 57:1438-1444

32. Tahara M, Kawagishi R, Sawada K, Morishige K, Sakata M, Tasaka K, Murata Y: Tocolytic effect of a Rho-kinase inhibitor in a mouse model of lipopolysaccharide-induced preterm delivery. Am J Obstet Gynecol 2005, 192:903-908

33. Dudley DJ, Branch DW, Edwin SS, Mitchell MD: Induction of preterm birth in mice by RU486. Biol Reprod 1996, 55:992-995

34. Lindström TM, Bennett PR: The role of nuclear factor kappa B in human labour. Reproduction 2005, 130:569-581

35. Keelan JA, Blumenstein M, Helliwell RJ, Sato TA, Marvin KW, Mitchell MD: Cytokines, prostaglandins and parturition: a review. Placenta 2003, 24:S33-S46

36. Slattery MM, Morrison JJ: Preterm delivery. Lancet 2002, 360 : 1489-1497

37. Taylor BD, Holzman CB, Fichorova RN, Tian Y, Jones NM, Fu W, Senagore PK: Inflammation biomarkers in vaginal fluid and preterm delivery. Hum Reprod 2013, 28:942-952
38. Ng PY, Ireland DJ, Keelan JA: Drugs to block cytokine signaling for the prevention and treatment of inflammation-induced preterm birth. Front Immunol 2015, 6:166

39. Condon JC, Jeyasuria P, Faust JM, Mendelson CR: Surfactant protein secreted by the maturing mouse fetal lung acts as a hormone that signals the initiation of parturition. Proc Natl Acad Sci U S A 2004, 101:4978-4983

40. Pirianov G, Waddington SN, Lindström TM, Terzidou V, Mehmet H, Bennett PR: The cyclopentenone 15-deoxy-delta 12,14-prostaglandin $\mathrm{J}(2)$ delays lipopolysaccharide-induced preterm delivery and reduces mortality in the newborn mouse. Endocrinology 2009, 150:699-706

41. Weber CK, Liptay S, Wirth T, Adler G, Schmid RM: Suppression of NF-kappaB activity by sulfasalazine is mediated by direct inhibition of IkappaB kinases alpha and beta. Gastroenterology 2000, 119: $1209-1218$

42. Nath CA, Ananth CV, Smulian JC, Peltier MR: Can sulfasalazine prevent infection-mediated pre-term birth in a murine model? Am J Reprod Immunol 2010, 63:144-149

43. Shahin AY, Hassanin IM, Ismail AM, Kruessel JS, Hirchenhain J: Effect of oral N-acetyl cysteine on recurrent preterm labor following treatment for bacterial vaginosis. Int J Gynaecol Obstet 2009, 104: $44-48$

44. Hamaya R, Ogawa M, Kobayashi N, Suzuki J, Itai A, Hirata Y, Nagai R, Isobe M: A novel IKK inhibitor prevents progression of restenosis after arterial injury in mice. Int Heart J 2012, 53: $133-138$

45. De Silva D, Mitchell MD, Keelan JA: Inhibition of choriodecidual cytokine production and inflammatory gene expression by selective IkappaB kinase (IKK) inhibitors. Br J Pharmacol 2010, 160. $1808-1822$

46. Ireland DJ, Kemp MW, Miura Y, Saito M, Newnham JP, Keelan JA: Intra-amniotic pharmacological blockade of inflammatory signalling pathways in an ovine chorioamnionitis model. Mol Hum Reprod 2015, 21:479-489

47. Singer M, Sansonetti PJ: IL-8 is a key chemokine regulating neutrophil recruitment in a new mouse model of Shigella-induced colitis. J Immunol 2004, 173:4197-4206

48. Lockwood CJ, Arcuri F, Toti P, Felice CD, Krikun G, Guller S, Buchwalder LF, Schatz F: Tumor necrosis factor-alpha and interleukin-1beta regulate interleukin-8 expression in third trimester decidual cells: implications for the genesis of chorioamnionitis. Am J Pathol 2006, 169:1294-1302

49. Jia X: Value of amniotic fluid IL-8 and annexin A2 in prediction of preterm delivery in preterm labor and preterm premature rupture of membranes. J Reprod Med 2014, 59:154-160

50. Jacobsson B, Holst RM, Wennerholm UB, Andersson B, Lilja H, Hagberg H: Monocyte chemotactic protein-1 in cervical and amniotic fluid: relationship to microbial invasion of the amniotic cavity, intra-amniotic inflammation, and preterm delivery. Am J Obstet Gynecol 2003, 189:1161-1167

51. Esplin MS, Peltier MR, Hamblin S, Smith S, Fausett MB, Dildy GA, Branch DW, Silver RM, Adashi EY: Monocyte chemotactic protein-1 expression is increased in human gestational tissues during term and preterm labor. Placenta 2005, 26:661-671

52. Payne MS, Bayatibojakhi S: Exploring preterm birth as a polymicrobial disease: an overview of the uterine microbiome. Front Immunol 2014, 5:595

53. Ilievski V, Lu SJ, Hirsch E: Activation of toll-like receptors 2 or 3 and preterm delivery in the mouse. Reprod Sci 2007, 14:315-320

54. Agrawal V, Smart K, Jilling T, Hirsch E: Surfactant protein (SP)-A suppresses preterm delivery and inflammation via TLR2. PLoS One 2013, 8:e63990

55. Romero R, Gotsch F, Pineles B, Kusanovic JP: Inflammation in pregnancy: its roles in reproductive physiology, obstetrical complications, and fetal injury. Nutr Rev 2007, 65:S194-S202 